OPEN ACCESS

Citation:Author (2021) Title. Phytopathologia Mediterranea 60(2): 351-379. doi: 10.36253/phyto-13021

Accepted: August 12, 2021

Published: September 13, 2021

Copyright: $\odot 2021$ Author. This is anopen access, peer-reviewed article published by Firenze University Press (http:// www.fupress.com/pm) and distributed under the terms of the Creative Commons Attribution License, which permits unrestricted use, distribution, and reproduction in any medium, provided the original author and source are credited.

Data Availability Statement: All relevant data are within the paper and its Supporting Information files.

Competing Interests: The Author(s) declare(s) no conflict of interest.

Editor: Alan Phillips, University of Lisbon, Portugal.
Review

\section{Fomitiporia mediterranea M. Fisch., the historical Esca agent: a comprehensive review on the main grapevine wood rot agent in Europe}

\author{
Samuele MORETTI ${ }^{1, *}$, Andrea PACETTI ${ }^{1,2}$, Romain PIERRON ${ }^{1}$, Hanns- \\ Heinz KASSEMEYER ${ }^{3}$, Michael FISCHER ${ }^{4}$, JeAn-Pierre PÉROS 5 , Gabriel \\ PEREZ-GONZALEZ ${ }^{6}$, Evie BIELER ${ }^{7}$, MARION SCHILLING $^{8}$, StEFANO DI \\ MARCO $^{9}$, Eric GELHAYE ${ }^{8}$, LAUra MUGNAI ${ }^{2}$, Christophe BERTSCH$^{1}$, \\ SIBYLLE FARINE ${ }^{1, *}$ \\ ${ }^{1}$ Laboratoire Vigne Biotechnologies et Environnement UPR-3991, Université de Haute \\ Alsace, 33 rue de Herrlisheim, 68000 Colmar, France \\ ${ }^{2}$ Department of Agricultural, Food, Environmental and Forestry Science and Technology \\ (DAGRI), Plant pathology and Entomology section, University of Florence, P.le delle Cas- \\ cine, 28, 50144 Firenze, Italy \\ ${ }^{3}$ State Institute for Viticulture, Plant Pathology \& Diagnostics, Merzhauser Str. 119, \\ 79100 Freiburg, Germany \\ ${ }^{4}$ JKI-Julius Kühn-Institute, Federal Research Centre for Cultivated Plants, Plant Protec- \\ tion in Fruit Crops and Viticulture, D-76833 Siebeldingen, Germany \\ ${ }^{5}$ UMR AGAP Institut, Université de Montpellier, CIRAD, INRAE, Institut Agro, F-34398 \\ Montpellier, France \\ ${ }^{6}$ Department of Microbiology, University of Massachusetts, Amherst, MA 01003, USA \\ ${ }^{7}$ University of Basel, Swiss Nanoscience Institute - Nano Imaging Lab, Basel, University of \\ Basel, Klingelbergstrasse $50 \mathrm{CH}-4056$ Basel, Switzerland \\ ${ }^{8}$ Université de Lorraine, INRAE, IAM, F-54000 Nancy, France \\ ${ }^{9}$ Istituto per la Bioeconomia, Consiglio Nazionale delle Ricerche, Via Gobetti 101, 40129 \\ Bologna, Italy \\ *Corresponding authors: samuele.moretti@uha.fr; sibylle.farine@uha.fr
}

Summary. Fomitiporia mediterranea M. Fisch. (Fmed) is a basidiomycete first described in 2002, and was considered up to then as part of Fomitiporia punctata (P. Karst) Murrill. This fungus can degrade lignocellulosic biomass, causing white rot and leaving bleached fibrous host residues. In Europe Fmed is considered the main grapevine wood rot (Esca) agent within the Esca disease complex, which includes some of the most economically important Grapevine Trunk Diseases (GTDs). This review summarises and evaluates published research on Fmed, on white rot elimination by curettage or management by treatments with specific products applied to diseased grapevines, and on the relationship between wood symptoms and Grapevine Leaf Stripe Disease (GLSD) in the Esca disease complex. Information is also reviewed on the fungus biology, mechanisms of pathogenicity, and their possible relationships with external foliar symptoms of the Esca disease complex. Information on Fmed control strategies is also reviewed.

Keywords. Fmed, Basidiomycete, white rot, wood symptoms, foliar symptoms. 


\section{INTRODUCTION}

Grapevine Trunk Diseases (GTDs), mainly comprising Botryosphaeria dieback, Eutypiosis and the Esca disease complex, are widespread in vineyards (Mugnai et al., 1999; Bertsch et al., 2013; Bruez et al., 2013; Mondello et al., 2018a). These diseases significantly affect grapevine productivity causing yield losses and quality degradation affecting wine alcohol content and flavour components (Mugnai et al., 1999; Lorrain et al., 2012; Calzarano et al., 2001, 2017).

For several decades the only effective pesticides used to control GTDs were sodium arsenite, to reduce the leaf stripe foliar symptoms in the Esca complex of diseases (Ravaz, 1919; Bonnet, 1926; Rui and Battel, 1963; Svampa and Tosatti, 1977; Del Rivero and García-Marí, 1984), and the fungicides benomyl and carbendazim, to reduce infections by the agents of Eutypiosis and Botryosphaeria dieback, respectively (Magarey and Carter 1986; Ramsdell, 1995). All these pesticides were banned in European countries in the early 2000s because of their potential environmental and/or user toxicities, more than 10 years after GTDs and especially Esca disease complex were becoming acute problems in Europe and in other grapevine growing countries. GTDs have been described as "the biotic stress of the century" for grapevines (Songy et al., 2019a), and all wine-growing countries are likely to be affected by these diseases. In France, the National Grapevine Trunk Disease Survey assessed incidence and evolution of GTDs during a 10 year survey period. Up to $13 \%$ of productive vines were affected by GTDs in French vineyards (Grosman, 2008; Grosman and Doublet, 2012; Bruez et al., 2013). In Italy, incidence of GTDs was between 8 to 19\% (Romanazzi et al., 2009), and was of average annual incidence of $12 \%$ in vineyards younger than 10 years (Abbatecola et al., 2000), or up to $63 \%$ in 30 year old vineyards (Surico et al., 2000).

In several countries within and outside Europe, there has been an upward trend of GTDs since the end of the 20th century (Mugnai et al., 1999; Wicks and Davies, 1999; Rubio and Garzón, 2011; Úrbez-Torres et al., 2014; Fontaine et al., 2016a; Guérin-Dubrana et al., 2019; Kraus et al., 2019). GTDs have also caused severe economic losses. These have been estimated as up to \$US 260 million in California (Siebert, 2001) for GTDs, and \$US 2000 to 3000 per hectare for "Esca disease" (Vasquez 2007, in Rubio and Garzón, 2011), and approx. one billion euros in wine production due to GTDs in France (reported in 2014 by IFV, the French Wine Institute). Annual financial costs of dead vine replacements in all wine production countries were estimated to be 1.132 billion euros (Hofstetter et al., 2012). These losses have been the major reason that professional winegrowers, research agencies, financial consortia and the scientific community have concentrated on GTDs research in recent decades.

The complexity of symptoms and fungi involved in these diseases is great, and this is particularly true for "Esca disease" (in this paper, when the literature data refer to this generic term - as well as when we will arbitrarily refer to this generic term to avoid nomenclature confusion when critically discussing the literature - we will place quotation marks around the term "Esca disease"). Historically, Esca, a word of indo-european origin meaning "food", tinder for fire, used to indicate "amadou" i.e. white rot (Viala, 1922, on the chapter written by Gard in "Bulletin de la Societé de Pathologie Vegetale", 1922; Montanari, 2010), had been used for a grapevine wood rot disease. Later, the term was associated with foliar symptoms, described as chronic or acute forms (Viala, 1926; Larignon and Dubos, 1997; Letousey et al., 2010; Lecomte et al., 2012), and was shown to involve several different symptoms associated with different pathogens. It was then proposed as a disease complex involving multiple pathogens including basidiomycetes and/or ascomycetes (Mugnai et al., 1999; Surico, 2009; Bertsch et al., 2013). These caused separate diseases including: $i$ ) white rot (Esca) that develops mostly in old vines; $i$ ) vascular diseases, widely present in propagation material and young vines (brown wood streaking of grape cuttings and Petri disease); and iii) Grapevine Leaf Stripe Disease (GLSD), which has an unusual epidemiology and symptomatology that can be associated with some or all of the wood pathogens, i.e. only vascular and canker agents, or, very often, also wood decay in all possible combinations. The condition where white rot (Esca) and GLSD occur together can be indicated as "Esca proper", in recognition of the original disease description.

The frequency of GLSD foliar symptoms has increased considerably over the last two decades. A preliminary study (Fussler et al., 2008) indicated mean incidence increase of $3.25 \%$ for "Esca disease" (leaf stripe and apoplexy symptoms) in France between 2003 and 2005. "Esca disease" and Eutypiosis were responsible together for $10 \%$ of vine replacements in Alsace (Kuntzmann et al., 2010). Also in France, Bruez et al. (2013) showed that incidence increase varied according to region. In Austria, Reisenzein et al. (2000) estimated a $2.7 \%$ annual increase of plants showing "Esca disease" foliar symptoms. In Italy, Surico et al. (2006) indicated an increase from 30 to $51 \%$ between 2000 and 2006, and Romanazzi et al. (2009) showed how disease incidences reached 60 to $80 \%$ in many old vineyards of south- 
ern Italy. A comprehensive survey for 22 European and Mediterranean vine-growing countries (COST Action; Guérin-Dubrana et al., 2019) described GLSD trends in most surveyed countries as "increasing" and/or "worrying", particularly in France, Italy, Spain and Turkey. In Germany, in 12 intensively pruned vineyards of red and white grape varieties and resistant and traditional cultivars, incidence of GLSD increased from $1.9 \%$ in 2015 to $3.6 \%$ in 2018, and was greatest in 2017 at $4.5 \%$ of vines affected (Kraus et al., 2019).

Some observations on Esca complex of diseases are now well accepted, despite the complexity, terminology evolution, and difficulties in understanding the interactions of variables that affect symptom expression. These include:

i) The interactions with environmental, pedo-climatic and agronomic factors/practices that can affect symptom expression and disease severity (Marchi et al., 2006; Calzarano et al., 2018a; Lecomte et al., 2018; Fischer and Peighami-Ashnaei, 2019; Songy et al., 2019a).

ii) No completely resistant grape cultivar has been reported, but cultivar and clone contributions to symptom expression and severity have been observed and reviewed (Marchi, 2001; Quaglia et al., 2009; Murolo and Romanazzi, 2014; Kraus et al., 2019; Moret et al., 2019; Songy et al., 2019a; Moret et al., 2021).

iii) The nutritional (especially macronutrient) status of vines can affect foliar symptom expression (Calzarano et al., 2009, 2021).

iv) Although the presence of an exceptionally wide mycoflora in Esca- and GLSD-affected vines has been confirmed by meta-barcoding (Del Frari et al., 2019a; Niem et al., 2020), the pathogens most frequently associated with the wood infections are the two Ascomycota Phaeomoniella chlamydospora (W. Gams, Crous, M.J. Wingf. \& L. Mugnai) (Crous and Gams, 2000) (Pch) and Phaeoacremonium minimum (Tul. \& C. Tul.) Gramaje, L. Mostert \& Crous (Gramaje et al., 2015) (Pmin) (syn. Phaeoacremonium aleophilum), while the most frequently isolated basidiomycete in Europe has been Fomitiporia mediterranea M. Fisch. (Fischer, 2002) (Fmed). The two Ascomycota species have mostly been associated with the "phaeotracheomycotic complex" (brown wood streaking, Petri disease and GLSD; Bertsch et al., 2013), while Fmed or the other basidiomycetes causing wood decay (Fischer and González-García, 2015) have only been associated with white rot, Esca and "Esca proper". Nevertheless, decay elimination (curettage) reduced foliar symptoms, and correlations between white rot extent, elimination and foliar symptom expression have been reported (Maher et al., 2012; Thibault, 2015; Cholet et al., 2019, 2021; Pacetti et al., 2021).
Fomitiporia mediterranea (as Fomitiporia punctata) was shown to be a primary pathogen by artificial inoculations, either in vineyards or in greenhouse experiments (Sparapano et al., 2000a; 2001a). The need for specific successions of fungi in wood colonization to detoxify wood cellular microenvironments from excesses of polyphenols produced by plant reactions has been suggested but was never fully proved (Larignon and Dubos, 1997; Mugnai et al., 1997; Amalfitano et al., 2000). Microbial combinations between Fmed, Pch and some bacterial taxa (i.e. Sphingomonas spp. and Mycobacterium spp.) may have a role in the onset of "Esca disease" in young vines (Bruez et al., 2020). Synergism between Fmed and bacteria such as Paenibacillus spp. for grapevine wood component degradation has also been confirmed (Haidar et al., 2021).

Despite the year-to-year fluctuations in incidence, foliar symptom surveys represent simple and non-invasive ways to indirectly assess grapevine wood infection by Esca complex pathogens, and for determining epidemiology, crop losses and health status of vineyards (Guérin-Dubrana et al., 2013). Claverie et al. (2020) summarised knowledge on foliar symptom outbreak in the "toxins hypothesis" and "hydraulic dysfunction hypothesis". The first describes how phytotoxic compounds produced by "Esca disease"-associated fungi could diffuse through host transpiration stream sap flow to leaves, inducing the typical tiger-striped leaf patterns (Abou-Mansour et al., 2004; Bruno and Sparapano, 2006b; Andolfi et al., 2011). The second hypothesis explains how impairment of sap flow to leaves, mainly caused by vessel occlusions/ pathogen compartmentalization, could lead to cavitation contributing to foliar symptom expression (Pouzoulet $e t$ al., 2014, 2017, 2019). Recent findings, however, suggest how these two hypotheses can be complementary and not exclusive, due to observed association between foliar symptoms, disruption of vessel integrity and presence of some "Esca disease"-associated pathogens presence in host trunks, which could elicit a distance-response (Bortolami et al., 2019). Stem vessel occlusion has been related to exacerbation of foliar symptom expression in the following growth season (Bortolami et al., 2021).

Because the two Ascomycota Pch and Pmin have frequently been associated with foliar symptoms of "Esca disease"-symptomatic plants, considerable research has been carried out on Pch and Pmin biology and pathogenicity, and a more comprehensive and integrated view on these species was presented by authors such as Valtaud et al. (2009), Mostert et al. (2006) and Gramaje et al. (2015). The same cannot be affirmed for Fmed. Despite progress made since taxonomic description of this fungus (Fischer, 2002), knowledge on the pathogen, its wood 


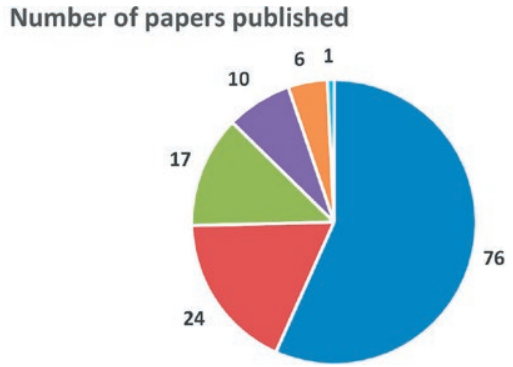

Figure 1. Number of published papers dealing with Fomitiporia mediterranea from 2002 (Fmed identification date) to 2021, as indexed in the Web of Science ${ }^{\mathrm{TM}}$ database (Thomson Reuters).

degradation process and relationship with the other Esca complex diseases, is fragmented. There are few reviews which consider Fmed as part of "Esca disease" or GTDs in general, and to our knowledge no comprehensive review on Fmed alone has been undertaken (Figure 1).

For this reason, along with contrasting reports of correlations between amounts of white rot necrotic tissues (thus Fmed presence) and the leaf stripe symptoms (Maher et al., 2012; Bruez et al., 2014; Bruez et al., 2020; Cholet et al., 2021; Pacetti et al., 2021), and reports of little or no correlation between these factors (Edwards et al., 2001; Calzarano and Di Marco 2007; Romanazzi et al., 2009; Mugnai et al., 2010), a review of Fmed is necessary, in order to collect knowledge of the fungus itself, and to stimulate scientific debate and novel ideas in the context of GTDs.

\section{BASIDIOMYCETES ASSOCIATED WITH ESCA}

Knowledge on basidiomycetes associated with "Esca disease" has increased, and Fischer (2006), Fischer and González-García (2015), and Cloete et al. (2015a, 2016) provided a comprehensive compendium on the topic. Ravaz (1909) was a pioneer in grapevine basidiomycete identification, with the putative identification of Phellinus igniarius (L.) Quél. (at the time Fomes igniarius (L.) Fr. and formerly Polyporus igniarius (L.) Fr. based on fruit bodies found on diseased grapevines in southern France). Vinet (1909) and Viala (1926) also reported the presence of Stereum hirsutum (Willd.) Pers. in French vineyards. These two basidiomycetes were long considered as causal agents of Esca wood decay but pathogenicity was only proven for P. igniarius (most likely a Fomitiporia sp.) by Chiarappa (1997).

Studies on "Esca disease" and its etiology multiplied in the late 1990s, especially when Larignon and Dubos (1997) isolated Phellinus punctatus (P. Karst.) Pilát from Esca wood decay in French vineyards. After studies of the infrageneric structure of Phellinus s.l. by Fiasson and Niemelä (1984), Fischer (1996) and Wagner and Fischer (2001, 2002), P. punctatus was grouped within Fomitiporia, as F. punctata (P. Karst) Murrill (= P. punctatus). Multiple surveys of Italian vineyards by Cortesi et al. (2000) concluded that the main cause of decay in Escaaffected vines was $F$. punctata, later recognized as the new species F. mediterranea (Fischer 2002), which is now considered the main white rot agent in "Esca disease" in Europe and Mediterranean regions.

Stereum hirsutum was isolated by Larignon and Dubos (1997) from central decayed grapevine wood inhabited by putative P. igniarius, but its role in GLSD is still debated, although it is clearly a white rot basidiomycete agent. Some authors have suggested that this fungus has little or no role in the Esca complex of disease because it is found only rarely in vineyards (Mugnai et al., 1999; Cortesi et al., 2000; Reisenzein et al., 2000; Vicent et al., 2001). In any case, S. hirsutum may act as a weak facultative parasite, occasionally penetrating the heartwood of host plants and producing very limited infections and decay of the inner host tissues (Fischer and González-García, 2015).

Many other basidiomycetes have been isolated from decaying grapevine wood. White et al. (2011) characterised ten possibly novel taxa belonging to Hymenochaetales associated with "Esca disease", i.e. white rot on GLSD symptomatic vines. For Europe, an annotated checklist of GTD-related basidiomycete taxa has been published (Fischer and González-García, 2015). With the advent of metagenomic approaches, reports of basidiomycetes are increasing (Del Frari et al., 2019a; Bruez et al., 2020). A recent study by Brown et al. (2020) aimed to clarify the relevance of basidiomycete colonisation within the Esca complex of diseases. They isolated many taxa (including new species, such as Inonotus vitis A.A. Brown, D.P. Lawr. \& K. Baumgartner, Tropicoporus texanus A.A. Brown, D.P. Lawr. \& K. Baumgartner, and Fomitiporia ignea A.A. Brown, D.P. Lawr. \& K. Baumgartner) from white rot and black/brown discoloured wood collected from grapevine plants expressing GLSD foliar or shoot symptoms in Californian and Texan vineyards.

More Fomitiporia spp. have been associated with "Esca-diseased" grapevines in other regions, including Fomitiporia australiensis M. Fisch., Jacq. Edwards, Cunningt. and Pascoe in Australia (Fischer et al., 2005), Fomitiporia polymorpha M. Fisch. in California (Fischer and Binder, 2004), Fomitiporia capensis M. Fisch., M. Cloete, L. Mostert, F. Halleen in South Africa (Cloete et al., 2014), F. ignea (Brown et al., 2020) in Texas, and, more recently, Fomitiporia punicata Y.C. Dai, B.K. Cui \& Decock in China (Ye et al., 2021), originally described 
on Punica granatum (Dai et al., 2008). As well, Fomitiporia erecta A. David, Dequatre \& Fiasson, and F. punctata were mentioned as occurring on grapevine in Spain (Fischer and González-García, 2015). Of these species, $F$. australiensis, $F$. capensis and F. ignea were exclusively documented from grapevine.

Geographic distribution and host range of Fmed have probably expanded in recent decades. This is supported by the number of host plants in the different regions. In Central Europe the host range is largely limited to Vitis vinifera, given the scarcity of reports of the fungus on other hosts: i.e. on Laurus nobilis (Fischer, 2006) and on Robinia pseudoacacia (Schmidt et. al., 2012). However, Fmed occurs on several other hosts in the Mediterranean area (see below). This discrepancy in the reported host range indicates a recent invasion of the fungus into the viticultural regions of Central Europe, possibly associated with climatic changes leading to increased temperatures in this region.

These observations indicate that intrinsic geographic and climate conditions play roles in diffusion of Basidiomycota pathogens and influence spread of Fomitiporia spp. in vineyards (Fischer et al., 2005; Fischer, 2006; Cloete et al., 2014). Geographical variations influence distribution of fungi among different locations (Hofman and Arnold, 2008; Dietzel et al., 2019), and climate is a major abiotic factor shaping fungal biogeography (Castillo and Plata, 2016; Větrovský et al., 2019). Spatial analyses of "Esca-disease"-related basidiomycete taxa, and comprehensive screening of possible non-Vitis host plants, preferably from proximity of vineyards, could help to identify key pedo-agroclimatic factors affecting their diffusion, and could indicate why some Fomitiporia spp. are retrieved from some areas but not others.

In Europe information on grapevine white rot agents began to be revised in 2002: Fischer found that strains formerly acknowledged as $F$. punctata collected from grapevines in Italy and Germany differed from strains from other hosts and other geographic areas (Central Europe). Molecular diagnoses (ITS data), pairing tests of single spore isolates, compared with temperature preferences of cultured mycelia allowed description of the new species Fomitiporia mediterranea M. Fischer (Fischer, 2002). This is currently considered the main causal agent of white rot in "Esca diseased" grapevines in Europe and in Mediterranean climate areas, while F. punctata is more ubiquitous, although a European centred distribution has been suggested by Decock et al. (2007).

Due to indistinguishable morphology between Fmed and F. punctata, but the highlighted phylogenetic differences, previous isolates and findings attributed to $F$. punctata should be reconsidered as possibly assignable to
Fmed (Fischer, 2002; Ciccarone et al., 2004; Fischer, 2006). Recent findings on P. punctatus and P. pseudopunctatus A. David Dequatre and Fiasson by Polemis et al. (2019) and Markakis et al. (2019) have reinforced that possible misidentification led to the underestimation of $F$. mediterranea incidence in the Mediterranean region.

This review focuses only on Fmed and its role in Esca-related wood degradation, with careful reconsideration of previous reports where the pathogen may have been incorrectly identified.

\section{IDENTIFICATION, TAXONOMY, HOST RANGE, AND SYMPTOMS INDUCED IN GRAPEVINES}

Description of fruit bodies and mycelia

Morphology and anatomy of Fomitiporia mediterranea (Hymenochaetaceae, Hymenochaetales, Agaricomycetes, Basidiomycota) were described by Fischer (2002).

Fomitiporia mediterranea fruiting bodies (Figure 2) are resupinate, inseparable, and hard woody, up to 15 $\mathrm{mm}$ thick with yellowish-brown narrow margins, containing subglobose to oval basidiospores. The hyphal system is dimitic, with generative and skeletal hyphae. Detailed descriptions of the hyphal system, fruiting bodies and basidiospores of this fungus were provided by Fischer $(2002,2009)$ and Fischer and González-García (2015).

Figure 3, A, B and C show, respectively, a tube mouth with outgrowth of vegetative hyphae, outgrowing hyphae from naturally infected grapevine wood and the pore surface of a fruiting body of $F$. mediterranea.

After isolation from infected wood and/or fruit bodies, mycelial isolates may develop into a so-called "bleaching type" (Type B: Fischer, 1987) or a "staining type" (Type S: Fischer, 1987) (Figure 4).

Type B mycelium has a cottony to woolly appearance, and aerial hyphae are yellowish to brown. Medium pigmentation is sparse or absent. Type S-mycelium has sparse aerial hyphae, and medium pigmentation is strong. Colony growth after 14 days at $21^{\circ} \mathrm{C}$ on Malt Extract (ME) agar in complete darkness was more rapid in bleaching-type isolates (colony diameter $=3.0$ to 4.5 $\mathrm{cm})$ than staining-type isolates $(1.5$ to $2.5 \mathrm{~cm}$ ). The two mycelium types may alternate over ensuing inoculations. Growth was confirmed between 15 and $35^{\circ} \mathrm{C}$, with optimum growth at $30^{\circ} \mathrm{C}$ (Fischer, 2002, 2006; Fischer and Kassemeyer, 2003). Under laboratory conditions, sporulation is absent in Fmed. Spore germination tests with spores from actively sporulating fruit bodies were performed for some Fmed strains, indicating very low germination rates (less than $1 \%$ ) with a high variation in germination times (Fischer, 2002). 


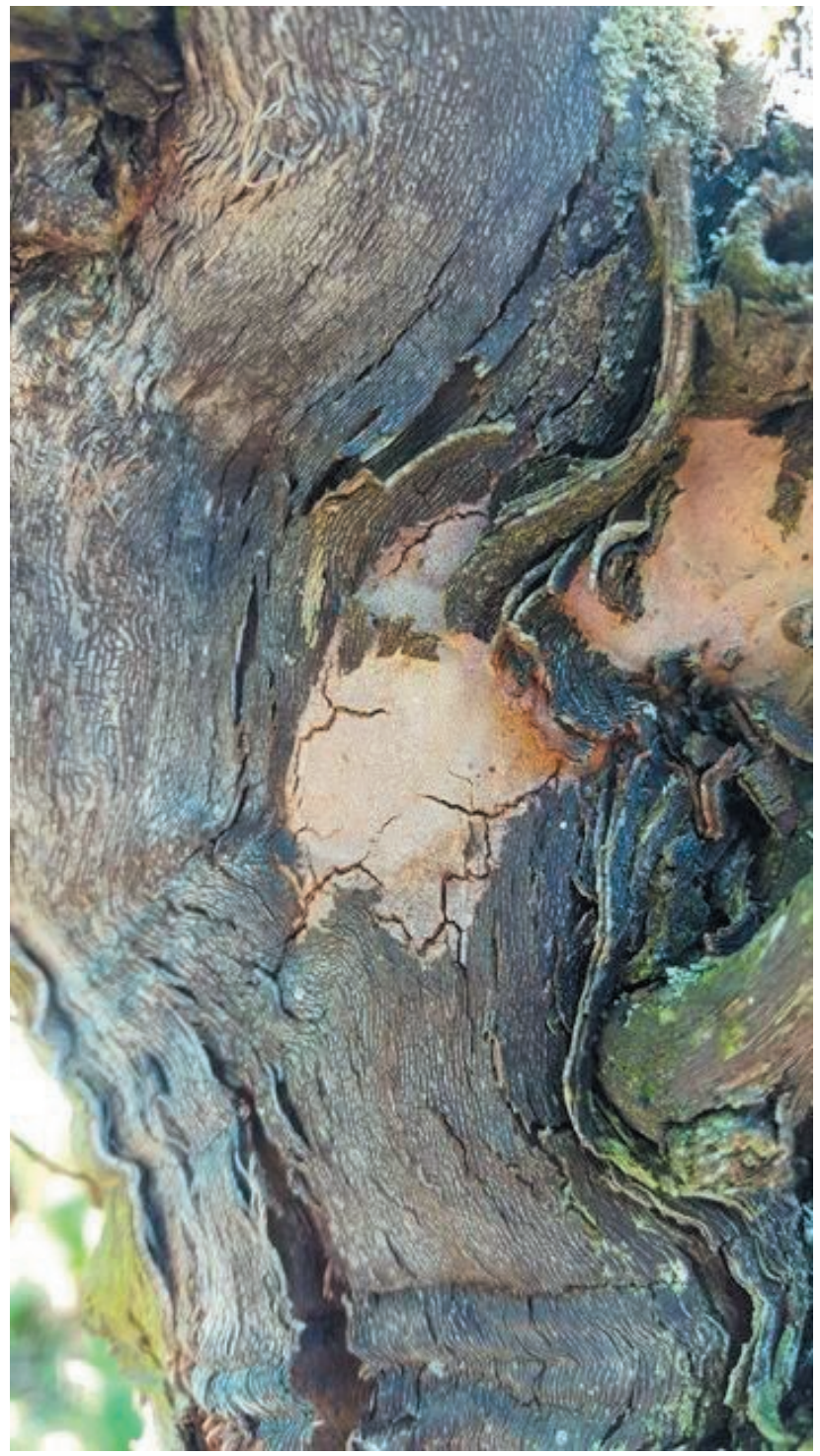

Figure 2. Fruiting bodies of Fomitiporia mediterranea on a grapevine trunk. Photograph taken in July 2018, from 'Sauvignon Blanc', in a vineyard in Ehrenkirchen, Germany.

Spread by basidiospores is considered the main dispersal form for Fmed and this has been described to be mainly via rain and wind (Cortesi et al., 2000). In Central European vineyards, fruiting body sporulation is increased after rainy periods and is related to daily temperatures greater than $10^{\circ} \mathrm{C}$ and relative humidity greater than $80 \%$ (Fischer, 2009).

\section{Mating system}

Studies of the Fmed mating system were also affected by misidentification of the pathogen. Fischer

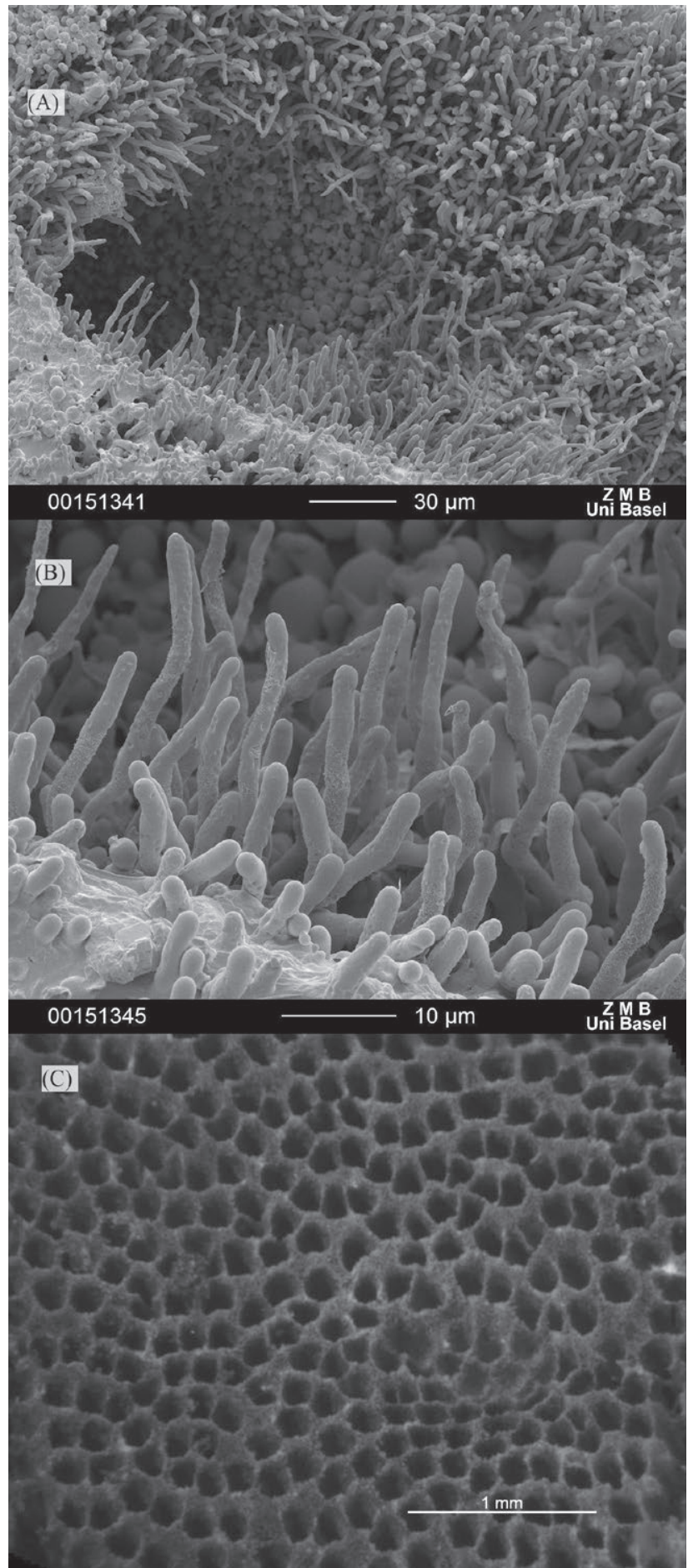

Figure 3. (A), Cryo-Scanning-Electron-Microscopy (Cryo-SEM) micrograph ( $\times 500$ magnification) of an Fmed tube mouth showing outgrowth of vegetative hyphae. (B), Cryo-SEM micrograph $(\times 2,000)$ of hyphae in a cross section of a grapevine trunk naturally affected by white rot. (C), Stereo micrograph of the surface of an Fmed fruiting body $(\times 50)$ The pores are $5-8 / \mathrm{mm}$. The diseased grapevine specimen was collected in a vineyard in Pfaffenweiler, south-west Germany. 


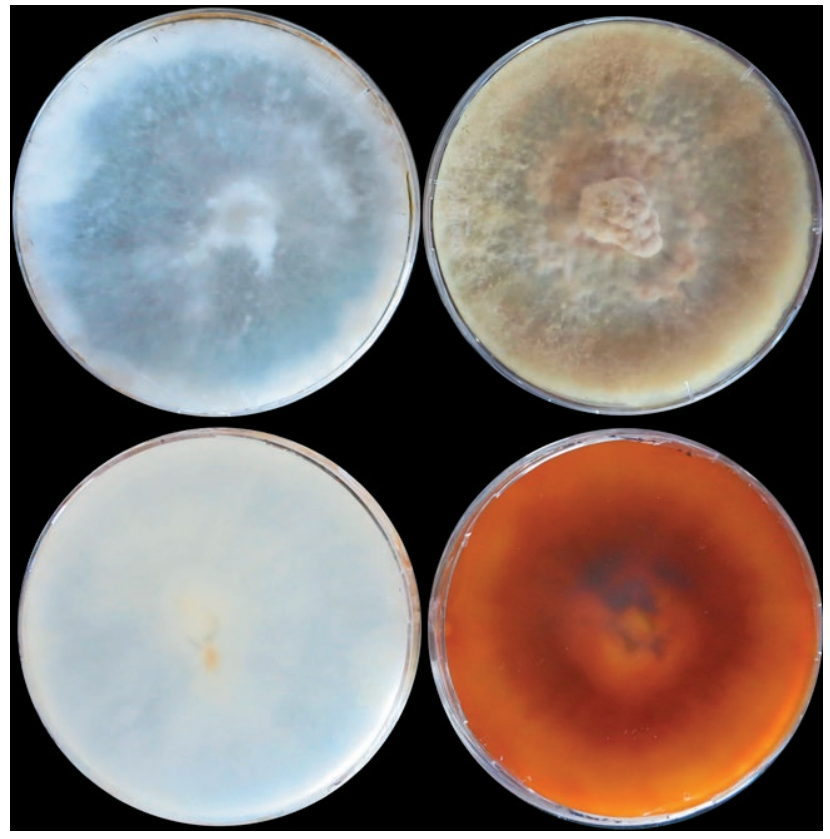

Figure 4. Mycelium cultures of Fomitiporia mediterranea on malt extract agar (ME) after 28 days of incubation. "Type B" (left, surface and reverse side) and "Type S" (right, surface and reverse side).

(1996) described F. punctata strains (later distinguished from Fmed) as homothallic, with no mating types evident in pairings of spores originating from one fruiting body. The time lag between separation of Fmed from $F$. punctata by Fischer (2002) and the research of JamauxDespreaux and Péros (2003) initially provided conflicting reports of the homothallic mating system described for the fungus. Jamaux-Despreaux and Péros (2003) observed outcrossing populations in France and Italy. This was indicated by high genetic variation within and between vineyards, and random assortment of genetic markers. They therefore suggested possible existence of non-outcrossing populations in other areas. Following correct assignment of species, it was shown that Fmed was a heterothallic bipolar species (Fischer, 2002), while F. punctata was confirmed as homothallic.

A variety of pairing tests were conducted by Fischer (2002), who demonstrated a range of compatible and incompatible reactions (see Fischer, 2002 for details). Growth of secondary mycelia was stronger in compatible inter-strain than in intra-strain pairings. Mycelia formed from inter-strain pairings could prevail under natural conditions, resulting in high outcrossing rates.

It is now accepted that basidiomycete mating is regulated by different genes, grouped in two types of homeodomain transcription factors (HD genes), in pheromones genes and their related receptors and response genes $(P R$ genes). These genes can reside in linked or un-linked chromosome loci (James et al., 2006; Kües et al., 2013, 2015). James et al. (2013) highlighted at least four $H D$ (two pairs of HD1 and two pairs of HD2), and several apparently functional $P R$ genes in the Fmed genome, such as 2 STE3, several MAP kinases and 3 Prf1. These authors also suggested that the genes were not linked in a unique mating locus (James et al., 2013; Kües et al., 2015).

Further pairing tests, perhaps with other strains, could better clarify the dispersal system of the fungus, and identify other possible intersterility groups. This would be further clarified if genetic variability data retrieved from German vineyards were considered. Fischer (2012) found 14 different Fmed genotypes out of 15 fruit bodies, all derived from one vineyard. Lentes and Fischer (personal communication) identified 56 genotypes out of 64 isolated mycelia, derived from different vines in two vineyards in the Moselle region of Germany.

Available Fmed genome could provide new information for expression analysis of mating-associated genes, especially in response to changing environmental conditions which are increasingly affecting European vineyards. Increasing this knowledge could provide a better understanding on pathogen spread and genetic recombination, since Fomitiporia spp. are well adapted to different conditions and climates, as reflected by their biogeographical variability.

\section{Field identification}

Compared to white rot presence, fruiting bodies of Fmed are very rarely found in vineyards, mostly on the uppermost parts of trunks, near pruning wounds, which are the main sites of infection (Cortesi et al., 2000; Fischer et al., 2005; Fischer, 2006; Fischer and GonzálezGarcía, 2015). In vineyards in Central Europe, Fmed fruiting bodies were only present on 1 to $3 \%$ of "Escadiseased" grapevines that were older than 15 years (Fischer, 2009), and the pathogen was detected as vegetative mycelium in infected hosts. In Germany, a 100:1 ratio is mentioned by Fischer (2006) indicating a low co-occurrence of vegetative mycelium with white rot and fruiting bodies. This was also reported in Tuscan vineyards by Cortesi et al. (2000). Because compatibility groups were identified (Fischer, 2002), the occasional occurrence of fruiting bodies in vineyards may be partly explained by the possibly rare contact between sexually compatible basidiospores (Jamaux-Despreaux and Péros, 2003). Dead grapevine trunks are the most favourable substrates for development of fruiting bodies, and the dead trunks are usually removed from vineyards. Another hypothesis to explain the low ratio between white rot and fruiting bodies in non-Central European countries is that the disease 
Table 1. Host range and geographic distribution of Fomitiporia mediterranea M. Fischer 2002. For each host (and each country), the table includes first reports which used classical isolations, and some of the significant subsequent reports/studies which used molecular classification and metagenomic approaches. References accompanied by " $\dagger$ ” refer to studies which used former classifications (as Phellinus punctatus or F. punctata) which should be carefully reconsidered as representing F. mediterranea.

\begin{tabular}{|c|c|c|}
\hline Host & Country & References \\
\hline \multirow[t]{15}{*}{ Vitis vinifera } & Algeria & Berraf and Péros, 2005 \\
\hline & Austria & Fischer et al., 2006 \\
\hline & Czech Republic & Baranek et al., 2018 \\
\hline & France & $\begin{array}{l}\text { †Larignon and Dubos, 1997; †Jamaux-Despreaux and Péros, 2003; Péros et al., 2008; Laveau et al., } \\
\text { 2009; Kuntzmann et al., 2010; Ouadi et al., 2019; Bruez et al., } 2020\end{array}$ \\
\hline & Germany & $\begin{array}{l}\text { Fischer, 2002; Fischer and Kassemeyer, 2003; Fischer, 2006; Fischer, 2012; Fischer and González- } \\
\text { García, 2015; Fischer, } 2019\end{array}$ \\
\hline & Greece & ${ }^{\dagger}$ Rumbos and Rumbou, 2001 \\
\hline & Hungary & Rábai et al., 2008 \\
\hline & Iran & $\begin{array}{l}\text { †Karimi et al., 2001; Farashiyani et al., 2012; Mohammadi et al., 2013; Rajaiyan et al. 2013; Amarloo } \\
\text { et al.,2020; Mirabolfathy et al., } 2021\end{array}$ \\
\hline & Italy & $\begin{array}{l}{ }^{\dagger} \text { Mugnai et al., 1999; }{ }^{\dagger} \text { Cortesi et al., 2000; Ciccarone et al., 2004; Romanazzi et al., 2009; Quaglia et } \\
\text { al., 2009; Del Frari et al., 2019a; Girometta et al., 2020; Pacetti et al., } 2021\end{array}$ \\
\hline & Lebanon & Choueiri et al., 2014 \\
\hline & Portugal & Sofia et al., 2006 \\
\hline & Slovenia & Rusjan et al., 2017 \\
\hline & Spain & $\begin{array}{l}{ }^{\dagger} \text { Armengol et al., 2001; Martin and Cobos, 2007; Sánchez-Torres et al., 2008; Luque et al., 2009; } \\
\text { Garcia Benavides et al., 2013; Elena et al., } 2018\end{array}$ \\
\hline & Switzerland & Fischer, 2006 \\
\hline & Turkey & Akgül et al., 2015 \\
\hline Acer negundo & Italy & Fischer, 2002 \\
\hline \multirow[t]{2}{*}{ Actinidia spp. } & Greece & ${ }^{\dagger}$ Elena and Paplomatas, 2002 \\
\hline & Italy & Fischer, 2002; Di Marco et al., 2004a; Di Marco and Osti, 2008; Girometta et al., 2020 \\
\hline Albizia julibrissin & Greece & Markakis et al., 2017 \\
\hline Cistus sp. & Italy & Girometta et al., 2020 \\
\hline \multirow[t]{2}{*}{ Citrus spp. } & Greece & Elena et al., 2006 \\
\hline & Italy & Roccotelli et al., 2014 \\
\hline Corylus avellana & Italy & Pilotti et al., 2010; Girometta et al., 2020 \\
\hline Elaeagnus angustifolia & Iran & Ahmadyusefi and Mohammadi, 2019 \\
\hline Fagus sylvatica & Italy & Girometta et al., 2020 \\
\hline Fortunella japonica & Greece & Markakis et al., 2017 \\
\hline Hedera helix & Italy & Girometta et al., 2020 \\
\hline Lagerstroemia indica & Italy & Fischer, 2002 \\
\hline Laurus nobilis & Slovenia & Fischer, 2006 \\
\hline Ligustrum vulgare & Italy & Fischer, 2006 \\
\hline \multirow[t]{2}{*}{ Olea europaea } & Greece & †Paplomatas et al., 2006; Markakis et al., 2017; Markakis et al., 2019 \\
\hline & Italy & Fischer, 2002 ; Carlucci et al., 2013 \\
\hline Platanus $x$ acerifolia & Italy & Pilotti et al., 2005 \\
\hline Prunus dulcis & Spain & Olmo et al., 2017 \\
\hline Punica granatum & Greece & Markakis et al., 2017 \\
\hline Pyrus communis & Greece & Markakis et al., 2017 \\
\hline Quercus ilex & Italy & Fischer, 2006 \\
\hline Quercus robur & Italy & Girometta et al., 2020 \\
\hline Quercus rubra & Italy & Girometta et al., 2020 \\
\hline \multirow[t]{2}{*}{ Robinia pseudoacacia } & Italy & Fischer, 2006; Girometta et al., 2020 \\
\hline & Germany & Schmidt et al., 2012 \\
\hline Salix alba & Italy & Girometta et al., 2020 \\
\hline Ulmus spp. & Iran & Mirsoleymani and Mostowfizadeh Ghalamfarsa, 2019 \\
\hline
\end{tabular}


and fungus structures could occur in several alternative hosts within or near vineyards (see Table 1). These sources of inoculum could be important. The discrepancies between occurrence of vegetative mycelia and fruit bodies are often large in lignicolous fungi. While the existence of $F$. mediterranea fruiting bodies may be underestimated (Fischer 2006), precise evaluation of exogenous inoculum sources remains a challenging issue.

Field identification of Fomitiporia spp. on grapevines is often complex. Because fruiting bodies are very rare and have very similar morphologies, molecular diagnoses after isolations from infected wood tissues or fruiting bodies are likely to be the most reliable tools for identification of mycelia not clearly assignable to particular species (Ciccarone et al., 2004).

Overview of molecular diagnosis, taxonomy and phylogeny

Amplifications and sequencing of ITS regions with or without Large Sub-Unit (LSU) translation elongation factor subunit 1-a (tef1) and the second largest subunit of RNA polymerase II (RPB2) sequence analysis, have permitted new advances in classification of grapevine basidiomycetes using specific primers. Reports are increasing, differentiating new Fomitiporia species (Cloete et al., 2016; Chen and Cui, 2017; Brown et al., 2020; Chen et al., 2021; Ye et al., 2021).

Fischer (2002) reported a specific method for identification, based on the nuclear encoded ribosomal DNA region ITS1-5.8S-ITS2 using the primer pair prITS5 and prITS4 (White et al., 1990). Compared to other Fomitiporia spp., Fmed strains showed unique small insertions in both ITS regions: between nucleotides 201 and 206 (AATAAT) in ITS1 and between nucleotides 748 and 745 (CCTTTGA) in ITS2 (Fischer, 2002; 2006; Fischer and Binder, 2004). Since 2006, specific primers based on these insertions have been available for differentiation of Fmed from other species such as F. punctata and F. australiensis (Fischer, 2006). The primer sequences and characteristics are as follows: prFmed $1,5^{\prime}$ GCA GTA GTA ATA ATA ACA ATC 3' $(\mathrm{GC}=28.6 \%$, TM $=50.1^{\circ} \mathrm{C}$ ); and prFmed $2,5^{\prime}$ GGT CAA AGG AGT CAA ATG GT 3' $\left(\mathrm{GC}=45 \%, \mathrm{TM}=55.3^{\circ} \mathrm{C}\right)$. A 550 bp product is only obtained for Fmed. Parameters for successful amplification were described by Fischer (2006).

With basidiospores being the main dissemination agent of Fmed, considerable genetic variation in F. punctata (probably Fmed) has been described by Random Amplified Polymorphic DNA (RAPD) markers. This variation has been shown among isolates derived from individual vineyards (Pollastro et al., 2000; Jamaux-Despreaux and Péros, 2003). Pollastro et al. (2001) successfully developed sequence-characterised amplified region (SCAR) primers suitable as a molecular diagnostic tool for Fmed.

The primer pair ITS1 and ITS4 (White et al., 1990) have also been successfully used for identification of Fmed isolates within an Italian mycological collection based on fresh mycelial isolates (Girometta et al., 2020).

Other Fomitiporia species recorded from grapevine include: F. polymorpha, F. capensis, $F$. australiensis, $F$. ignea, F. erecta, F. punctata, and F. punicata. For F. polymorpha, F. australiensis, F. erecta and F. punctata, characterization of the ITS1-5.8S-ITS2 region was sufficient either to describe them as separate species, or to establish phylogenetic relationships with other Fomitiporia spp. (Fischer and Binder, 2004; Fischer et al., 2005; Fischer and González-Garcia, 2015). Implication of other conserved genetic regions has distinguished these other species above metioned, using the LSU unit ribosomal RNA-enconding regions tef1 and RPB2 together with ITS data to describe them (Cloete et al., 2014; Brown et al., 2020; Ye et al., 2021). Nevertheless, species-specific primers are available only for Fmed (Fischer, 2006), although unique forward primers paired with ITS4 primers have been designed to successfully detect F. capensis (Bester et al., 2015).

\section{Host range and geographical distribution}

Fomitiporia mediterranea is considered to be a highly adaptable species, based on the diversity of host plants, and occurrence in different regions and climates.

Isolates from grapevine were retrieved from a range of climate conditions, according to the most updated version of the original Köppen-Geiger climate classification map (Geiger, 1961; Beck et al., 2018): from "Mediterranean and temperate humid-subtropical climates" (for most of non-Central European isolates of the pathogen), to "arid and semi-arid climate" (for Algerian, Iranian and some of the non-Central European isolates), to "cool temperate climate" (for most of the Central-European isolates)" (see Figure 5 for the detailed geographical distribution of Fmed). Throughout its geographical range, Fmed shows close affinity with $V$. vinifera. However, this may be due to the economic significance of grapevine in these regions, resulting in detailed field observations for vineyards compared with other woody hosts. The fungus is also found on other host plants outside non-Central European countries, potentially resulting in increased infection pressure on grapevines (see Table 1 for a detailed list of hosts in different countries). Fischer $(2002,2006)$ postulated that, at least for non-Central European countries, alternative hosts could be foci for development of Fmed fruiting bodies, reinforcing the observed high adaptability of the pathogen to mul- 


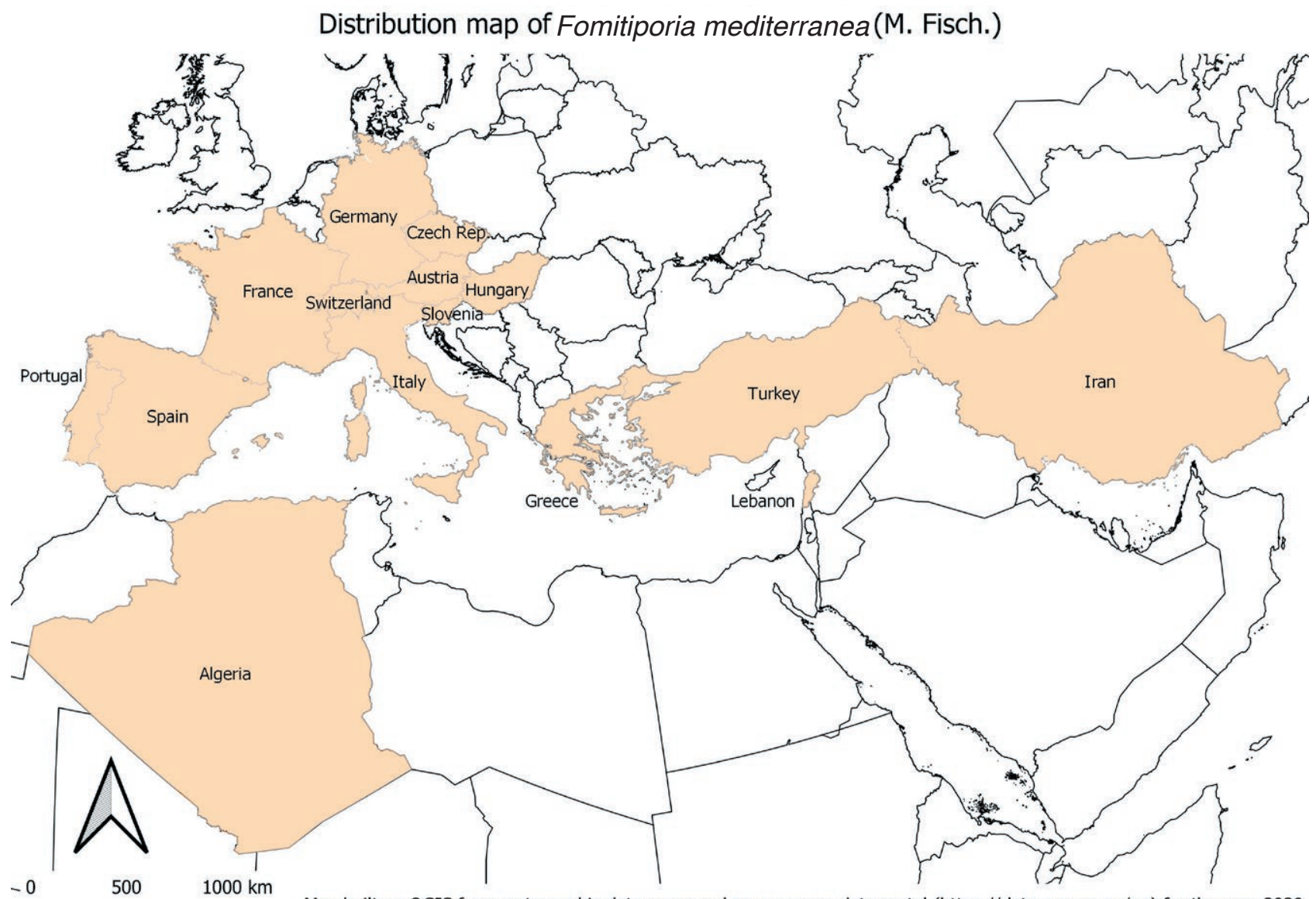

Figure 5. Distribution of Fomitiporia mediterranea, based on published reports of isolation of the fungus from grapevine, Vitis vinifera. The map was constructed using QGIS software (version 3.10.9-A Coruña).

tiple host species. Although current data show only very few isolations of Fmed from Central-European non-Vitis hosts, i.e. Robinia pseudoacacia in Germany (Schmidt et al., 2012) and Laurus nobilis in Slovenia (Fischer, 2006), the potential for the fungus to colonize other hosts is demonstrated. Future studies could focus on: $i$ ) surveys of fruiting body incidence on alternative hosts in the proximity of vineyards (to better assess inoculum sources); ii) performing comparative secretome and metabolome assessment of wood from different hosts to increase knowledge on Fmed colonization and growth and fruiting body development; and iii) determine pathogenicity to grapevine of isolates from different host plants.

Spread in grapevines and vineyards, wood symptoms and their relationships with foliar symptoms

Fomitiporia mediterranea is mainly retrieved from grapevine white rot necrotic tissue, although its presence in necrosis borders between white rot and non-necrotic tissues, and adjacent non-necrotic but recently colonised wood has been demonstrated (Fischer, 2002; Péros et al., 2008; Surico, 2009; Bruez et al., 2017; Elena et al., 2018; Bruez et al., 2021; Pacetti et al., 2021). The pathogen needs some time to colonise and decay woody tissues, explaining why it is predominantly found in trunks greater than 10 years old, and only to a lesser extent in young trunks (Sánchez-Torres et al., 2008; Fischer, 2009). White rot has also been mostly reported in old vineyards although it can be sometimes found in young vines and very occasionally in young GLSD symptomatic vines (Edwards et al., 2001; Mugnai et al., 2010).

In the Esca complex of diseases, several diseases have been recognised and have been related to infections by different fungi, and symptom expression can be influenced by many agronomic and environmental factors (cultural practices, host plant age, soil type, weather conditions) (Calzarano et al., 2018a; Gramaje et 
al., 2018; Lecomte et al., 2018). Distribution of symptomatic vines within a vineyard poorly indicates the dissemination mode of related fungi, including Fmed, but diseased vines can be found grouped along vineyard rows. This supports the hypothesis that human-mediated practices are involved in pathogen spread (Mugnai et al., 1999; Guérin-Dubrana et al., 2019). Research on F. punctata (likely Fmed) isolates obtained from different vines showed they belonged to different somatic incompatibility types (Cortesi et al., 2000), indicating that each vine was colonised by genetically distinct individuals. Similarly, results for F. punctata (likely Fmed) (JamauxDespreaux and Péros, 2003) on the genotypic differences at vineyard level strongly indicated outcrossing reproduction via basidiospores. These results are not consistent with the hypothesis that Fmed is spread through wounds by pruning tools. In addition to this genetic evidence, much epidemiological data has shown that "Esca disease" symptoms were spatially random in vineyards (Cortesi et al., 2000; Surico et al., 2000; Sofia et al., 2006, Li et al., 2017), which is consistent with the hypothesis that basidiospores are the likely agents of dispersal for Fmed (Cortesi et al., 2000; Fischer, 2002). Although sporulation is rare on grapevine trunks, the inoculum could come from the many other hosts of the pathogen.

Typically, Fmed induces white rot in innermost grapevine wood (Figure 6). The decay is most often observed in arms, stem heads and trunks, with colonisation starting from pruning wounds and extending along entire trunks, mostly in the central parts but occasionally also at trunk bases, with desuckering wounds as entrance points (Larignon and Dubos 1997; Mugnai et al., 1999, 2010; Sparapano et al., 2000a, 2001a; Fischer, 2002; Fischer and Kassemeyer, 2003).

Rot diameters vary and decrease from infection origin points to boundaries with healthy wood (Mugnai et al., 2010). Rootstocks are rarely affected because vines die before white rot reaches rootstock tissues, although white rot has been reported in rootstock tissues (Maher et al., 2012; Elena et al., 2018). However, Fmed-related white rot is common in rootstock mother plants (Fischer, 2019).

The main symptom induced by Fmed on grapevines is spongy yellowish or bleached decay in wood tissues, but the relationship between wood and external foliar symptoms of "Esca diseased" grapevines is debated. To the best of our knowledge, Lafon (in 1921) was the first author to make this association. He assumed that P. ignarius (most likely a Fomitiporia sp.) present in the decay was the main agent responsible for the apoplectic form of "Esca disease" and leaf dessication (due to sap flow impairment). However, information on Fmed,

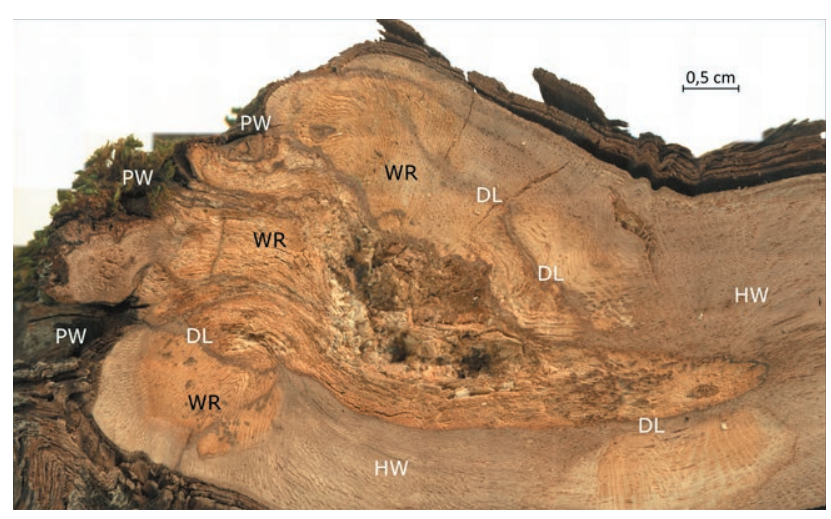

Figure 6. Macroscopic observation by stereo microscopy ( $\times 12$ magnification) of a cross section ( $1 \mathrm{~cm}$ thick) of the head of a grapevine stem with a large area of white rot (WR) spreading from pruning wounds (PW) into healthy wood (HW). The necrotic zones are separated from the healthy wood by demarcation lines (DL). Specimen collected in May 2021 from a 28-year-old 'Sauvignon Blanc' plant, from a vineyard in Pfaffenweiler, south-west Germany.

grapevine wood symptoms and foliar symptoms needs to be re-examined. Demonstration of Fmed to act as a primary grapevine pathogen - after artificial inoculations by mycelial plugs or toothpicks (Sparapano et al., 2000a, 2001a) - confirms the importance of this pathogen within the Esca disease complex. However, research on the actual colonization sequence of "Esca disease"-associated fungi in field-grown grapevines is still required to increase knowledge of relationships between wood decay and foliar symptoms. Under field conditions, basidiospores can be infection agents, and artificial basidiospore inoculations in greenhouses would help to determine the colonization ability of Fmed and its role in foliar symptoms. However, basidiospores are difficult to obtain, and rarely germinate under laboratory conditions (Fischer, 2002). Therefore reviewing studies from last two decades will provide insights on the impacts of Fmed on "Esca disease" foliar symptoms (GLSD).

Different types of necrosis have been described in "Esca diseased" wood (Larignon and Dubos, 1997). White rot necrosis clearly shows the presence of Fmed, which has been the main isolation source of this pathogen in Europe (Larignon and Dubos, 1997; Mugnai et al., 1999; Bruez et al., 2017). Through logistic regression analyses in an old 'Cabernet Sauvignon' vineyard, Maher et al. (2012) analysed data from presumably 20 to 25 year-old vineyards, and assumed white rot to be the tissue type most strictly associated with the leaf stripe symptoms. A relationship between Fmed and "Esca disease" foliar symptoms (GLSD) was shown if white rot presence overcame a $10 \%$ necrosis threshold, in vine grafts and/or cordons. Using a similar approach, Calzarano and Di Marco (2007) 
showed that, in 32- and 36-year-old vineyards, there was no relationship between severities of wood deterioration and external foliar symptoms. The leaf-symptomatic vines percentage with discoloration (but no white rot) was $46.2 \%$ in 32 -year-old vineyards and $7.2 \%$ in 36 -yearold vineyards. Both of these findings have been supported by other authors. Bruez et al. (2014) found white rot tissue in cordons from $79 \%$ of GLSD-symptomatic 10-yearold vines. Fischer (2012) found 100\% of 366 trunks of 28-year-old 'Traminer' vines to be affected by white rot, but less than $10 \%$ had foliar symptoms. Fischer (2019) also reported a possible correlation between the presence of Fmed (but also other GTD related fungi) and leaf symptoms in rootstock mother plants. Ouadi et al. (2019) observed white rot on 15 to $50 \%$ of the total necrotic area of trunks and cordons in 16-year-old 'Cabernet Sauvignon' grapevines expressing foliar symptoms. Edwards et al. (2010), after fully dissecting trunks of ten GLSD symptomatic vines (aged 4 to 7 years) detected white rot in only one vine. Mugnai et al. (2010) dissected nine symptomatic 5- and 6-years-old vines. They found that four of the vines had no white rot and five had traces of decayed wood, mainly following infections from desuckering wounds (Mugnai et al., 2010). These results confirm that white rot, and Fmed as the main white rot agent in Europe, becomes increasingly present as vines age, thus becoming increasingly associated with leaf symptoms. The pathogen may play a fundamental role in activating mechanisms leading to the onset of leaf stripe symptoms. However, observations of foliar symptoms not linked to white rot suggest that even if Fmed plays a very important role, other factors are also likely to be involved.

In 10-year-old 'Cabernet Sauvignon' cordons expressing foliar symptoms, Bruez et al. (2020) using meta-barcoding, proposed the link between the onset of GLSD with white rot and a combination of Fmed, Pch as well as Sphingomonas spp. and Mycobacterium spp. They suggested that microbiota interactions in white rot necrotic tissues could induce production of phytotoxic secondary metabolites, or increase some shared metabolic pathway, thereby inducing typical GLSD foliar symptoms. In vitro production of fungal secondary metabolites by co-culture with bacteria has been documented (Haidar et al., 2016), but occurrence in natural conditions is yet to be assessed.

Cholet et al. (2021) and Pacetti et al. (2021) have also shown the correlation of white rot with foliar stripe symptoms. Decay elimination (curettage, see below for details) drastically reduced GLSD symptoms during the years following curettage treatment, in 24-year-old 'Sauvignon Blanc' and in 14-year-old 'Cabernet Sauvignon' plants. Another interesting correlation between white rot and foliar symptoms came from the curative side: recently, Bruez et al. (2021) shown how after sodium arsenite treatment (see below for details), 25-year-old 'Gewürztraminer', 27-year-old 'Chardonnay' and 40-year-old 'Merlot' plants did not shown any foliar symptoms.

In conclusion, the relationship between outbreak of foliar symptoms and white rot in the Esca complex of diseases is widely supported and linked to Fmed in Europe, although this is not exclusive as the fungus is absent in young symptomatic vines. Nevertheless, clarifying the mechanisms involved in this relationship will be a big step towards full understanding of the processes leading to the characteristic symptoms and symptom expression timing of GLSD (the symptom fluctuations is not found in other diseases of perennial hosts). Several hypotheses have been proposed for etiology of leaf stripe symptoms, but to understand the role of Fmed in development of the disease, an important and essential first step is to detect the signals reaching the leaves and causing the outbreak of these symptoms. In the case of Fmed we suggest the following etiology: i) joint action of extracellular enzymes and toxins (from Fmed or the entire white rot microflora); ii) vascular system destruction caused by lignocellulolytic enzymes; iii) the formation of low molecular weight diffusible compounds from Fmed or from wood degradation-host infection reactions; and iv) a combination of these situations and the wood cellular microenvironment.

\section{GENOMIC INFORMATION}

Many fungal Agaricomycetes genomes have been sequenced by the Joint Genome Institute (JGI) (http:// jgi.doe.gov/fungi) (Grigoriev IV et al., 2011). According to these data, 93\% of the Agaricomycotina sequenced genomes are from Agaricomycetes. This could be related to the roles of these fungi in trees decay and to their potential applications in biotechnology (Lundel et al., 2014; Hyde et al., 2019). In a comparative genomic study, Floudas et al. (2012) sequenced the Fmed genome. The final draft assembly was obtained by in silico combination of Roche (454), Sanger Fosmids, and Illumina data. Information on genome annotation statistics and composition are available at the MycoCosm portal (https:// mycocosm.jgi.doe.gov) (Grigoriev IV et al., 2014) and in Floudas et al. (2012).

Fmed genome size is approx. $63.35 \mathrm{Mbp}$ which accounts for 11,333 predicted complete gene models with start and stop codons. The genome shows a conspicuous repetitive sequence component, mostly represented by microsatellites and Transposable Elements (TEs). It is 
generally accepted that repetitive sequences play roles in Basidiomycota genome rearrangements and gene mutations, interrupting genome linearity between strains, and producing strain polymorphisms (Castanera et al., 2017). This could at least partially explain the level of polymorphism detected between strains of Fmed (Pollastro et al., 2001). Specifically, 4157 microsatellites were detected, most of them (52.27\%) being dinucleotides, followed by tri-, mono-, penta-, hexa- and tetra-nucleotide microsatellites. TE analysis revealed a high proportion of TEs coverage (41.42\%), representing the greatest for the sequenced genomes in the study. The biggest portion of TEs was LTR-Gypsy elements (21.33\%), followed by LTRCopia, TIR, DNA-transposons and Helitrons. A consistent number of non-classified TEs were reported (Floudas et al., 2012).

Besides constitutive analysis of the genome, Floudas et al. (2012) conducted a comparative study with 30 fungal genomes (presenting different ecological strategies), to establish the origin of ligninolytic activity. Through molecular clock analysis of genes encoding Class II Peroxidases (PODs: responsible for lignin degradation), it was possible to date the appearance of ligninolytic activity and the Agaricomycetes ancestor (a white rot agent, most likely). The activity probably appeared approx. 290 $\mathrm{Ma}$ ago (between the end of Carboniferous and Permian period, Paleozoic era). Subsequently, by Class II PODsencoding gene expansion through the lineage, five orders of basidiomycetes differentiated, including the Hymenochaetales (most likely approx. $237 \mathrm{Ma}$, during the Triassic period, Mesozoic era). Fmed was estimated to have up to 17 Class II PODs-encoding genes in its genome, and these genes can possibly be found clustered with cellobiose dehydrogenase $(\mathrm{CDH})$ encoding genes and other unclassified genes.

Other gene copy numbers expanded in the lineage during Fmed genome evolution, such as genes encoding for glycoside hydrolases (GH) families, Fe (III)reducing glycopeptides (GLP), dye-decolourizing peroxidases (DyP) and laccases (Lac) (Floudas et al., 2012). A detailed report on carbohydrate active enzymes (Cazymes) and class II PODs is presented below.

\section{PATHOGENICITY}

In vivo white rot basidiomycete pathogenicity studies on grapevine have been rarely documented (Chiarappa, 1997; Larignon and Dubos, 1997; Sparapano et al., 2000a, 2000b, 2001a; Gatica et al., 2004; Laveau et al., 2009; Luque et al., 2009; Diaz et al., 2013; Akgül et al., 2015; Cloete et al., 2015b; Amarloo et al., 2020; Brown et al., 2020), but contrasting results to fulfil Koch's postulates were obtained, and the role of basidiomycetes as causes of grapevine foliar symptoms (GLSD) is not clear. Experiments have been conducted either on young or old grapevine plants, but very few of these studies used Fmed as inoculum (Larignon and Dubos, 1997; Sparapano et al., 2000a, 2000b, 2001a; Laveau et al., 2009; Luque et al., 2009; Akgül et al., 2015; Amarloo et al., 2020).

The first pathogenicity study on F. punctatus (probably Fmed) was conducted in France by Larignon and Dubos (1997) to determine the pathogen's role in wood decay. After fungus inoculation of healthy 'Cabernet Sauvignon' wooden blocks or rooted canes, they observed formation of typical white rot only in wooden blocks. As expected the fungus only colonised old wood.

Sparapano et al. (2000a), inoculating old vines and assessing wound-induced wood discolouration and white rot symptoms, found that inoculation with F. punctata (probably Fmed) produced the symptoms with different timing dependant on the cultivar, host plant age and portion inoculated. Specifically white rot formation tooks: i) approx. 6 months after inoculation for symptoms to occur in trunks, branches and spurs of 6-yearold 'Italia', and 9-year-old 'Matilde' plants; ii) 2 years after inoculation of 13-year-old 'Sangiovese' vines spurs and branches; or iii) 2 years after inoculation in 2-yearold rootstock Kober 5BB grafted with 'Italia'. No symptoms on leaves were induced. While F. punctata re-isolation was successful, no other wood degrading fungi were re-isolated. Sparapano et al. (2000a) concluded that $F$. punctata (probably Fmed) could act as a primary pathogen, and was able to colonize the grapevine woody tissues without other previous fungal infections when inoculated through wounds.

To gain details on the role of each fungus in "Esca disease", Sparapano et al. (2000b, 2001a) studied fungusto-fungus and fungus-to-plant interactions, both in vitro and in planta co-inoculations. Sparapano et al. (2000b) showed in vitro competitive interaction of $F$. punctata (probably Fmed) with P. chlamydospora and antagonism between $P$. aleophilum (=P. minimum) and $F$. punctata. They also observed that each fungus could act as a primary pathogen by in planta inoculations. Moreover, the effect of F. punctata (probably Fmed) on the woody tissue of 'Italia' and 'Matilde' grapevines was limited by $P$. aleophilum ( $=P$. minimum) but not by $P$. chlamydospora. Only $F$. punctata (probably Fmed) alone was able to induce white rot. This fungus was re-isolated, but no foliar symptoms were observed in the co-inoculation experiments. Besides confirming the fungus-to-fungus competitive and antagonistic interactions with Pch and P. aleophilum (= P. minimum), Sparapano et al. (2001a) 
found that $F$. punctata causes wood discolouration followed by limited and localised white rot lesions within 3 years after single-inoculations or all possible co-inoculations, in 5-year-old 'Italia' and 9-year-old 'Matilde' vines, when they were inoculated in the spurs, spreading slightly more rapidly when trunks of plants were inoculated. Fungus re-isolation was always successful, and few foliar symptoms (even though not fully corresponding to the typical tiger stripe pattern) were observed after 2 to 3 years from inoculation in all the inoculation combinations. Non-inoculated plants (experimental controls) did not develop foliar symptoms.

The most recent study of Fmed pathogenicity was conducted by Amerloo et al. (2020). They inoculated Fmed mycelium on 2-year-old rooted grapevine 'Kolahdari' cutting under controlled greenhouse conditions, obtaining wood discolourations (but not white rot) 10 months after inoculation, confirming that white rot formed only on old wood. The proportion of Fmed reisolation was approx. $60 \%$, and no foliar symptoms were recorded. These results were in agreement with findings in rooted cuttings of 'Cabernet Sauvignon' (Laveau et al., 2009), 1-year-old 'Macabeo' and 'Tempranillo' plants grafted onto Richter 110 rootstock (Luque et al., 2009), and 1-year-old rooted plants of 'Sultana Seedless' (Akgül et al., 2015).

Data from pathogenicity tests of Fmed and grapevine are still too scarce for postulation of general concepts, especially considering that multiple factors could play a role in wood symptoms appearance (i.e. grapevine cultivar, age, trunk portion). However, the experimental evidence on ability of the pathogen to primarily colonize grapevine wood, and on relationships between white rot presence/amount and external foliar symptoms, require further investigation, especially considering contrasting results obtained from artificial inoculations versus the ones obtained from curative experiments (see above).

Host specificity should also be considered. Fmed isolates from different hosts have been used for pathogenicity tests on citrus trees (Elena et al., 2006). According to the extent of wood discolouration in citrus trees after inoculation with Fmed isolates from Citrus, Vitis, or Actinidia, a degree of host specificity for Citrus spp. was suggested. Other cross-pathogenicity tests conducted by Markakis et al. (2017) shown a certain degree of host-specificity in Fmed: grapevine-isolates inoculated in wood of pomegranate tree and kumquat tree shown shorter wood discoloration (and no fungal re-isolation) than in pathogenicity test with isolates from the same trees.

Study of host specificity for different Fmed isolates could elucidate dissemination modes for Fmed.
As indicated above, most wood and/or foliar vine symptoms could be caused by enzymes, toxins and/or other metabolites secreted by the pathogens individually or in combinations spreading through vines from the colonised wood, together with products of host defence reactions (Sparapano et al., 1998; Graniti et al., 1999; Mugnai et al., 1999; Amalfitano et al., 2000, 2011; Sparapano et al., 2000a, 2000b; Bruno and Sparapano, 2006b; Claverie et al., 2020). Recently, wood degradation in grapevine diseases was critically reviewed in comparison with other tree species by Schilling et al. (2021), reinforcing our observation that studying enzymatic and non-enzymatic fungal degradation, together with host defence related compounds, could be the key to understanding fungal adaptation to grapevine, and provide insights into wood and foliar symptoms.

\section{Enzymes}

White rot in wood is the result of lignin, cellulose, and hemicellulose degradation (either simultaneously or preferentially) by extracellular enzyme activity (Blanchette, 1991). These enzymes include: i) carbohydrateactive enzymes (CAZymes), such as endoglucanases (EC 3.2.14), cellobiohydrolases (EC 3.2.1.91, classified in the Glycoside Hydrolase family, GH), $\beta$-glucosidases (EC 3.2.1.21) and cellobiose dehydrogenase, CDH (EC 1.1.99.18); ii) laccases (EC 1.10.3.2; p-diphenol:di-oxygen oxidoreductases); and iii) Class II peroxidases (PODs), such as manganese peroxidases (MnP; EC 1.11.1.13), lignin peroxidases (LiP; EC1.11.1.14) and the versatile peroxidases (VPs, EC 1.11.1.16) (Daniel, 2014). Auxiliary activities (AA) redox enzymes are also considered to be present in white rot agents: eight families of ligninolytic enzymes and two of lytic polysaccharide mono-oxygenases (LPMOs) are associated with CAZymes and Class II PODs, since they may contribute jointly to degradation of polysaccharides (Levasseur et al., 2013; Daniel, 2014). Carbohydrate-Binding Modules (CBMs) are noncatalytic modules which were also found to be associated with CAZymes, contributing to polysaccharide degradation activity (Boraston et al., 2004). All these enzymes are currently collected for each fungus in the Carbohydrate Active Enzymes database (CAZy database, https:// www.cazy.org), including its update for AA (http://www. cazy.org/Auxiliary-Activities.html) (Levasseur et al., 2013; Lombard et al., 2014).

Enzymes included in the pool of fungal secreted proteins, the secretome, can be involved in Fmed pathogenicity. Fomitiporia mediterranea and F. punctata (probably Fmed) secrete ligninolytic enzymes (such as laccases and peroxidases), and cellulolytic enzymes (such as endo- 
$1,4-\beta$-glucanases and $\beta$-glucosidases), for which in vitro activities in Fmed cultures have been assessed (Mugnai et al., 1999; Bruno and Sparapano 2006a). Laccases are known for their oxidase activity on a large set of phenolic compounds, and on non-phenolic compounds in the presence of mediators (Pérez et al., 2002). However, the role of laccases in plant-pathogen interactions is still discussed. Their importance in pathogenicity has been suggested for some fungal species, such as the chestnut blight pathogen Cryphonectria parasitica (Murrill) M.E. Barr, through tannin detoxification and involvement in several other metabolic pathways, such as fungal morphogenesis and pathogenesis (Singh Arora and Kumar Sharma, 2010). For Fmed, Abou-Mansour et al. (2009) purified a typical fungal $60 \mathrm{kDa}$ laccase from some isolates. This enzyme oxidizes many natural polyphenolic compounds. Complete lignin degradation was not achieved alone, however, but only with the contributions from ligninolytic class II PODs. Three manganese peroxidase genes supplementing laccase activity were characterized in the Fmed genome, as Fmmnp1, Fmmnp2 and Fmmnp3 (Morgenstern et al., 2010). Cloete et al. (2015b) highlighted the LiP activity of Fmed in vitro. It therefore appears that Fmed produces a complete white rot-type enzymatic pool, capable of oxidizing and mineralizing lignin and polysaccharides. In addition, comparative genomic studies supported laboratory data and highlighted a rich enzymatic pool for Fmed. Floudas et al. (2012) and Riley et al. (2014) showed that $C D H$ gene copies, several GH gene families, LPMOs and CBM family 1 (CBM1) genes were detected for the CAZymes pool. Other AAs were identified for lignin degradation pathways, including multicopper oxidases (MCO), copper radical oxidases (CRO), benzoquinone reductase, iron permease (FTR), and ferroxidase (Fet3) (Floudas et al., 2012). The genes encoding for the latter five proteins have been described as genes involved in the non-enzymatic wood degradation caused by some brown rot pathogens (Sista Kameshwar and Qin, 2020). This could support the hypothesis that a similar non-enzymatic iron-dependent system (as described by Goodell et al., 1997, for brown rot, and by Osti and Di Marco, 2010, for the Pch and Pmin soft rots) could also be part of the Fmed white rot process (Moretti et al., 2019). Low Molecular Weight Compounds (LMWC) $\mathrm{Fe}^{3+}$ reductants could also be involved in generating $\mathrm{OH}$ radicals through a mediated Fenton reaction $\left(\mathrm{Fe}^{2+}+\mathrm{H}_{2} \mathrm{O}_{2} \rightarrow \mathrm{Fe}^{3+}+\cdot \mathrm{OH}+{ }^{-} \mathrm{OH}\right)$, as suggested in the Chelator Mediated Fenton (CMF) model proposed by Goodell et al. (1997). Three studies support this hypothesis, including: $i$ ) the Fmed draft genome revealed a homologous SidA gene responsible for inducing siderophore biosynthesis in Ustilago maydis (DC.) Corda (Mei et al., 1993; Floudas et al., 2012; Canessa and Larrondo, 2013); ii) F. punctata (probably Fmed) produces LMW metabolites in vitro, some of which have iron-chelating ability (Sparapano et al., 2000b; Di Marco et al., 2001); and iii) the Fmed genome includes genes codifying for reducing-polyketide synthase (R-PKS) which upregulate in some brown rot fungi, and these have been related to LMWC production likely involved in the redox chemistry of non-enzymatic degradation models (Goodell et al., 1997; Riley et al., 2014; Goodell, 2020). These observations are in line with Riley et al. (2014), who observed that the lignocellulolytic gene pathway does not capture the prevailing paradigm of white rot/brown rot wood decay fungi over several Basidiomycota genomes. A more nuanced and less dichotomic categorization of rot types could be implemented.

The Fmed genome also includes several gene copies codifying for terpene synthase (TS), cytochrome P450 monoxygenase (CytP450) and glutatione transferases (GSTs) (Floudas et al., 2012). Together with R-PKS, TS could confer competition advantages against other microorganisms through secondary metabolite production (Riley et al., 2014). CytP450 could also be involved in secondary metabolite production, and was originally described with GSTs as part of fungal xenomes, often associated with intracellular detoxification processes against lignin and other secondary metabolites synthesized by plants in reaction to fungus attack (Morel et al., 2013). This could confer the "primary" pathogen character reported by Sparapano et al. (2000a, 2001a).

Degradative enzymes (such as laccases, peroxidases and tannases) produced by Fmed could also degrade antimicrobial substances synthetized by host plants (tannic acid and resveratrol), playing putative roles in host-pathogen interactions. Moreover, detoxification enzymes such as phenol-oxidases and peroxidases were also detected in the contact zones of dual cultures with Fmed and Pch or Fmed and Pmin, suggesting detoxification activity by these enzymes against antimicrobial substances secreted by antagonistic fungi (Bruno and Sparapano, 2006a).

In conclusion, studying the complexity of the enzymatic pool, the secretome and xenome, together with possible presence of a non-enzymatic iron-dependent pathway, could provide further insight into Fmed-grapevine interactions and "Esca disease" symptomatology.

\section{Phytotoxic compounds, organic acids, and other molecules}

Toxin production and translocation to foliage via sap flow has been often proposed as the possible cause of "Esca disease" foliar symptoms (Claverie et al., 2020), 
<smiles>O=Cc1ccc(O)cc1</smiles>
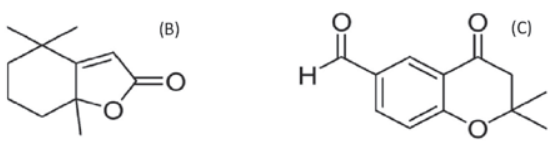

Figure 7. Phytotoxins produced by Fomitiporia mediterranea, based on relevant reports. (A), 4-Hydroxybenzaldehyde; (B), dihydroactinolide; (C), 6-Formyl-2,2-dimethyl-4-chromanone. Chemical formulae retrieved by PubChem (https://pubchem.ncbi.nlm.nih.gov/).

and its role in GTDs has recently been reviewed (Masi et al., 2018). It has been postulated that an oxidative burst triggered by the toxins in leaves could be more likely involved in foliar symptoms appearance than toxins themselves (Calzarano and Di Marco, 2018b). Toxicity thresholds and possible interference with other foliar susceptibility factors are still unclarified (Claverie et al., 2020). Production of low molecular weight metabolites with potential phytotoxicity was recorded (without identification) by Sparapano et al. (2000c), but phytotoxins were identified by Tabacchi et al. (2000) in F. punctata cultures (probably Fmed). They detected 4-hydroxybenzaldehyde, dihydroactinolide and 6-Formyl-2,2-dimethyl-4-chromanone (Figure 7), a phytotoxin related to eutypine produced by Eutypa lata (Deswarte et al., 1996a, 1996b; Andolfi et al., 2011). It was suggested that hydroxyl-benzaldehyde and its derivatives (carrying the aldehyde function) play important roles in the toxicity of fungi implicated in "Esca disease". Phytotoxicity was reported only for 4-Hydroxy-benzaldehyde on living protoplasts from $V$. vinifera 'Cabernet Sauvignon' at $10^{-5}$ and $10^{-6} \mathrm{M}$, as well as on callus from $V$. vinifera 'Gamay' grown in media supplemented with different concentrations of the metabolite $(100,250$, and $500 \mathrm{mM}$ ) (Tabacchi et al., 2000). Further research is necessary to fully assess phytotoxicity of fungal metabolites and their roles in the diseases of Esca complex.

There is good correlation between fungus pathogenesis and oxalic acid secretion (Dutton and Evans, 1996). This is especially true for wood decay agents, where organic acids (mainly oxalic acid) may facilitate lignocellulosic biomass degradation, due to $\mathrm{pH}$ acidification, unstable and toxic divalent metal chelation, and $\mathrm{H}_{2} \mathrm{O}_{2}$ production (Kuan and Tien, 1993; Shimada et al., 1994; Tanaka et al., 1994; Urzúa et al., 1998). Oxalic acid metabolism is mainly regulated by two enzymes, i.e. oxalate decarboxylase (ODC, EC 4.1.1.2) and oxalate oxidase (OXO, EC 1.2.3.4), both of which catabolize the organic acid and reduce its level, which in high concentrations could be cytotoxic for pathogenic fungi (Svedružić et al., 2005; Zhuang et al., 2015). For F. punctata (probably Fmed), despite $\mathrm{pH}$ lowering in liquid culture (from 6.8 to
5.3; Sparapano et al., 2000c), Liaud et al. (2014) observed no organic acid production by Fmed in a comparative liquid culture chromatography screening. However, the presence of oxalate decarboxylase/oxidases gene copies in the Fmed genome (Floudas et al., 2012) indicates that epigenetic regulation of their expression could often occur.

Basidiomycete species are well known to produce pigments in response to abiotic and biotic stimuli, and these pigments act as chemical mediators during interactions between multiple organisms. Among them, terpene polyketide and amino acid derivates are known to be inducible, and to confer competition advantage (Spiteller, 2008, 2015; Halbwachs et al., 2016). In co-culture assays with Hapalopilus rutilans (Pers.) Murrill, Fmed mycelium increased pigmentation earlier compared to axenic culture, via hyperproduction of hypholomine B (Tauber et al., 2018), suggesting a role in interaction modulation. Interactions of Fmed with other microorganisms has been studied by Bruno and Sparapano (2006a) and Sparapano et al. (2000b, 2001b). In dual cultures with Pmin on modified Czapek medium, Fmed colony margins turned brown, became thicker and aerial hyphae formed ridgelike barriers, but the fungus growth stops at the contact zone. In dual cultures with Pch, after agonistic early growth, Fmed overgrew Pch mycelium (Sparapano et al., 2000b). The Pmin vs F. punctata (probably Fmed) antagonistic effect was confirmed in triple cultures with Pch in that condition, Pch was not overgrown by the Fmed mycelium, suggesting a suppressive role of Pmin (Sparapano et al., 2000b). Sparapano et al. (2001b) also studied the possible biochemical motivation of these agonistic and not-agonistic effects: Pmin and Pch culture filtrates, depending on their dilution in culture media, inhibited or reduced growth of $F$. punctata in Malt Extract Agar (ME). No inhibition of Fmed in ME medium was observed for Pmin or Pch crude organic extracts (ethyl acetate extraction of culture filtrates), purified scytalone from Pmin and Pch (at $1 \mathrm{mg} \mathrm{mL}^{-1}$ ), pullulan from Pch (at $0.2 \mathrm{mg} \mathrm{mL}^{-1}$ ) and oligosaccharides up to $2.5 \mathrm{kDa}$ obtained by digestion of Pch-pullulan ( $\left.2 \mathrm{mg} \mathrm{mL}^{-1}\right)$ (Sparapano et al., 2001b).

Study of the metabolome and transcriptome of the contact zones of different dual cultures to assess molecular cross-talking between Fmed and its competitor, would be worthwhile, to complete the partially studied secretome of this pathogen (Bruno and Sparapano, 2006a).

\section{HOST PHYSIOLOGY CHANGES AND DEFENSE RESPONSES FOLLOWING F. MEDITERRANEA INFECTIONS}

Data is sparse on changes in grapevine physiology and defence mechanisms specifically related to Fmed. 
Effects of GTDs on grapevine physiology were reviewed by Fontaine et al. (2016b), but no specific responses to Fmed colonization and infection have been reported. Nevertheless, research on re-established plant vigour and quality grape production after 3 years from curettage treatments (see below) has demonstrated that white rot (where the main European decay agent Fmed is overabundant; Fischer and Kassemeyer, 2003; Bruez et al., 2017) probably affects grapevine physiology (Cholet et al., 2021). This follows observations by Ouadi et al. (2019) on 'Cabernet Sauvignon' plants presenting foliar symptoms of "Esca disease". They linked the abundance of necrotic wood (mainly white rot) in grapevine trunks and cordons with a $30 \%$ reduction in vine sap flow circulation, and thus leaf transpiration.

Few experiments have been performed to clarify plant defence mechanisms against Fmed. In callus/fungus dual culture experiments, Bruno and Sparapano (2006c) identified a number of phenolic molecules (benzaldehyde derivates, benzoic acid derivates, flavonols, flavonol-3-o glycosides, quercetin 3-rhamnoside, catechins and stilbenes) that were differentially induced in 'Matilde' and 'Italia' grapevines. Other studies have focused directly on vine sap (Bruno and Sparapano, 2006b, d) or brown-red symptomatic wood (Amalfitano et al., 2000, 2011; Agrelli et al., 2009) of "Esca disease"-symptomatic plants. Several stilbene-phenolic molecules were identified, which are theoretically toxic to Fmed, that showed greater sensitivity to phenols than Pch or Pmin (Amalfitano et al., 2001, 2011). Similar results were obtained by Rusjan et al. (2017) in wood of leaf stripe symptomatic vines, but with phenolic alterations reflecting both presence of the pathogen and wood condition in different parts of vines (trunks and rootstocks). Rusjan et al. (2017) proposed a relationship between the period of presence of the pathogen in different vine portions and their phenolic profiles. However, biomolecule concentration increases observed by Rusjan et al. (2017) may not be related exclusively to Fmed. Diseased plants are naturally infected by all the "Esca disease"-related fungi (Pch, Pmin, Fmed), and other possible microbial consortia highlighted by metagenomic approaches. Nevertheless, because a Fmed-Pch-Pmin interaction has been demonstrated, a relationship is likely between those compounds and Fmed (Sparapano et al., 2001b; Bruez et al., 2020). For this reason, results from most metabolomic studies in leaves responding to "Esca disease"-associated pathogens should be treated with caution, when attempting to understand exact plant responses to Fmed (Goufo et al., 2019; Moret et al., 2021). Further studies are necessary to precisely determine grapevine metabolite production burst specifically in response to Fmed colonization.
Damage to host hydraulic systems caused by the white rot necrosis could be the most important driver of physiological effects in grapevies, but specific studies are necessary to verify these hypotheses. To the best of our knowledge there have been no reported studies of wood compartmentalization specifically towards Fmed. The metabolic changes induced by Fmed in planta could generate biochemical markers for presence of the pathogen and wood degrading activity.

\section{CONTROL STRATEGIES WITH A FOCUS ON F. MEDITERRANEA}

Effective disease management is a major challenge in crop protection, and particularly for disease complexes such as "Esca disease". Efficiency of individual control methods for Esca complex of diseases is limited, and is best managed using integrated disease management, from nursery to vineyard. This includes cultural or remedial practices, vineyard sanitation, and use of pesticide chemicals or biological agents to protect grapevine wounds from pathogen infections (Gramaje et al., 2018). Methods to reduce or limit disease incidence, especially against Fmed infection, are outlined below.

\section{Disease resistance}

Incidence of "Esca disease" symptoms have been reported as cultivar-, rootstock-, and clone-related (Marchi 2001; Fussler et al., 2008; Grosman, 2008; Murolo and Romanazzi, 2014; Guan et al., 2016; Kraus et al., 2019; Moret et al., 2019), but they were all related to reduced presence of leaf symptoms, not to wood decay development. Some hypotheses could explain cultivar differences. Rolshausen et al. (2008) reported greater lignin levels in 'Merlot' grapevines tolerant to E. lata compared to susceptible 'Cabernet-Sauvignon' vines. A similar correlation has been suggested for Fmed affecting different olive tree varieties (Markakis et al., 2019). Assessment of susceptibility of wild grapevine ( $V$. vinifera subsp. sylvestris) to Fmed could be worthwhile, because this host has been shown to be a promising potential source of resistance to Botryosphaeria dieback (Guan et al., 2016). Some data are available on other Vitis genotypes used in resistance source trials (Kraus et al., 2019). Fischer (2019) also detected regular presence of Fmed vegetative mycelium in rootstock mother blocks of rootstocks SO4, 5BB and 125AA in Germany, all of which were a cross population of Vitis berlandieri $\times$ Vitis rupestris. 


\section{Grapevine propagation material}

The use of a good quality pathogen-free plant material is essential to limit inoculum propagation. Although Fmed has been shown to be present in blocks of rootstock mother vines (Fischer, 2009, 2019), and thus the derived plant material could be infected by "Esca disease"-associated fungi before nursery stages or during the propagation processes, Fmed has never been isolated from grafted 1-year old cuttings or propagation material. Furthermore, this pathogen has not been reported in grapevine nurseries (Larignon and Dubos 2000; Halleen et al., 2003; Zanzotto et al., 2007; Larignon et al., 2008a; Aroca et al, 2010; Gramaje and Armengol, 2011; Fischer, personal communication).

\section{Protective and curative disease control methods}

Curative control

Removing white rot from diseased grapevines seems to be efficient for reducing leaf stripe symptoms. This old technique, called "curettage" or "trunk surgery", consists of cutting affected vines and removing white rot with small precision chain saws. It provides good results; foliar symptoms are reduced even several years after curetting (Thibault, 2015). Cholet et al. (2021) demonstrated how curettage in "Esca disease"-symptomatic plants reduced foliar symptoms during 3 years after treatment, and re-establish vine vigour and grape production. Pacetti et al. (2021) confirmed foliar symptom remission in 14-year-old GLSD symptomatic 'Cabernet Sauvignon' vines for the following 2 years after complete trunk surgery, and demonstrated microbiome change induced by the treatment. Fomitiporia mediterranea abundance decreased after curettage, in parallel to an alpha-diversity increase in fungal population, suggesting a microbiota shift as a likely explanation for foliar symptom reduction during the post-curettage period.

Plant endotherapy is another promising curative technique against white rot. This includes direct treatment of white rot by drilling a vertical hole in grapevine trunks and injecting specific molecule solutions (typically fungicides), aiming to reduce foliar symptoms. However, due to the complexity of microbial consortia in diseased trunks, and because of the wood peculiar structure in old cultivated vines, specificity of the technique against Fmed needs to be refined. This approach is the subject of ongoing research (Gellon et al., 2017; Pacetti et al., 2019).

Sodium arsenite has been used in viticulture for a long time as the only effective and curative treatment against "Esca disease" (Songy et al., 2019b), and studies on modes of action of this compound are increasing. Larignon et al. (2008b) suggested Fmed as the most sodium arsenite sensitive "Esca disease"-associated fungus, and when Goddard et al. (2017) investigated the fate of arsenite within "Esca-diseased" treated plants, they found it concentrated in white rot necroses. Bruez et al. (2017) demonstrated that Fmed isolations were reduced from white rot necrotic tissue coming from sodium arsenite treated plants. Bruez et al. (2021) showed how in sodium arsenite treated 'Gewürztraminer', 'Chardonnay' and 'Merlot' vines (25 to 40 years old) expressing tiger stripe symptoms, the relative abundance of Fmed decreased in white rot necroses and necrosis boundaries, confirming Fmed as the most sodium arsenite sensitive among GTDs-associated fungi (Larignon et al., 2008b). Previously foliar symptomatic plants did not express these symptoms after treatment, suggesting that the positive effect of sodium arsenite on GLSD was from specific toxicity to Fmed in white rot necrotic tissues and their boundaries, where other parasitic and saprobic fungi (Inonotus hispidus Bull. P. Karst., Lepiota brunneoincarnata Chodat \& C. Martín) took place, increasing their relative abundance (Bruez et al., 2021).

Except for host endotherapy, for which experiments are ongoing, up to now curettage is likely to be the most sustainable physical management method against Fmed. More user- and environmentally-friendly chemical curative alternative should be proposed. The long-term efficacy of curative treatments has not been fully assessed. Data on reduction of foliar stripe symptoms provided by these two curative techniques (curettage and sodium arsenite) reinforce the link between GLSD and white rot, suggesting that more studies are required on these disease management approaches.

\section{Preventive control}

Protection of grapevine pruning wounds is an essential point to reduce pathogen entry (Eskalen and Gubler, 2001; Eskalen et al., 2007). In some European countries, some pesticide products (based on boscalid or pyraclostrobin) and biocontrol products (based on specific strains of Trichoderma spp.) are available for protection against GTDs. However, research with these products for management of Fmed diseases has not been reported yet.

Beside the authorized and registered products containing boscalid, pyraclostrobin or Trichoderma spp., many products or molecules have been tested in vitro for the control of GTD pathogens, and these were reviewed by Gramaje et al. (2018) and Mondello et al. (2018b). For Fmed, however, only few reports are available. Chitosan 
in in vitro tests gave a low $\mathrm{EC}_{50}$ value $\left(1.53 \mathrm{mg} \mathrm{L}^{-1}\right)$ for Fmed (Nascimento et al., 2007). Sensitivity of Fomitiporia spp. to chitosan was first reported by Bruno et al. (2001). Incorporation of resveratrol in culture media gave a direct antifungal effect against Fmed growth (Mazzullo et al., 2000). Copper oxychloride and gluconate formulations slightly reduced Fmed mycelium growth in vitro, with an $\mathrm{EC}_{50}$ of $11.242 \mathrm{mg} \mathrm{Cu} \mathrm{L}^{-1}$ (Di Marco et al., 2011). For biological control, sensitivity of Fmed to crude protein extracts (CPE) from Bacillus amiloliquefaciens AG1 has been recorded as $2.000 \mathrm{AU}$ $\mathrm{mL}^{-1}$ (Alfonzo et al., 2012). Del Frari et al. (2019b) demonstrated with in vitro dual culture plates that growth of Fmed and other "Esca disease"-associated fungi was inhibited by Epicoccum spp., a member of ascomycetes which have been commonly identified in grapevine microbiomes. No clear data have been provided about effects of Trichoderma spp. on Fmed, in contrast to documented effects of these fungi on the growth of Pch and E. lata (Di Marco et al., 2004b; John et al., 2005).

\section{CONCLUSIONS AND FUTURE PERSPECTIVES}

We have made careful attempts to collect and review all relevant published information on F. mediterranea, to stimulate debate within the GTD scientific community. Approximately 20 years after formal classification of this fungus, it is well established that it induces white rot in the grapevine wood, but details of the relationships between Fmed and GLSD essentially remain unknown. The causes and biomolecular mechanisms of white rot, and their relationships with external grapevine foliar symptoms, has yet to be deciphered, especially in light of knowledge and observations reviewed here. To fully describe these processes could be a standing point in the context of GTDs, and will allow viticulture to adopt new solutions for management of grapevine trunk diseases.

\section{LITERATURE CITED}

Abbatecola A., Dongiovanni C., Faretra F., Pollastro S., 2000. Observations on the fungi associated with Esca and on spatial distribution of Esca-symptomatic plants in Apulian (Italy) vineyards. Phytopathologia Mediterranea 39: 206-210.

Abou-Mansour E., Couché E., Tabacchi R., 2004. Do fungal naphthalenones have a role in the development of esca symptoms? Phytopathologia Mediterranea 43: 75-82.

Abou-Mansour E., Polier J., Pezet R., Tabacchi R., 2009. Purification and partial characterisation of a $60 \mathrm{KDa}$ laccase from Fomitiporia mediterranea. Phytopathologia Mediterranea 48: 447-453.

Agrelli D., Amalfitano C., Conte P., Mugnai L., 2009. Chemical and spectroscopic characteristics of the wood of Vitis vinifera cv. Sangiovese affected by esca disease. Journal of Agricultural and Food Chemistry 57(24): 11469-11475.

Ahmadyusefi Sarhadi F., Mohammadi H., 2019. Fomitiporia mediterranea and Phaeoacremonium rubrigenum associated to Russian olive trunk diseases in Iran. 4th Iranian Mycological Congress, Sari Agricultural Sciences and Natural Resources University, Sari, Iran. 26-28 August 2019: 104 (Abstract).

Akgül D.S., Gungor Savas N., Teker T., Keykubat B., Mayorquin J.S., Eskalen A., 2015. Fungal trunk pathogens of Sultana seedless vineyards in Aegean region of Turkey. Phytopathologia Mediterranea 54(2): 380-393.

Alfonzo A., Lo Piccolo S., Conigliaro G., Ventorino V., Burruano S., Moschetti G., 2012. Antifungal peptides produced by Bacillus amyloliquefaciens AG1 active against grapevine fungal pathogens. Annals of Microbiology 62: 1593-1599.

Amalfitano C., Evidente A., Surico G., Tegli S., Bertelli E., Mugnai L., 2000. Phenols and stilbene polyphenols in the wood of esca-diseased grapevines. Phytopathologia Mediterranea 39(1): 178-183.

Amalfitano C., Agrelli D., Arrigo A., Mugnai L., Surico G., Evidente A., 2011. Stilbene polyphenols in the brown red wood of Vitis vinifera cv. Sangiovese affected by "esca proper". Phytopathologia Mediterranea 50: S224-S235.

Amarloo O.A., Mohammadi H., Mahdian S.A., Tajick Ghanbary M.A., 2020. Identification and pathogenicity of fungal species associated with grapevine trunk diseases in Khorasan-Razavi province, Iran. Mycologia Iranica 7(1): 83-94.

Andolfi A., Mugnai L., Luque J., Surico G., Cimmino A., Evidente A., 2011. Phytotoxins produced by fungi associated with grapevine trunk diseases. Toxins 3(12): 1569-1605.

Armengol J., Vicent A., Torné L., García-Figueres F., García-Jiménez J., 2001. Fungi associated with esca and grapevine declines in Spain: a three-year survey. Phytopathologia Mediterranea 40(3): 325-329.

Aroca Á., Gramaje D., Armengol J., García-Jiménez J., Raposo R. 2010. Evaluation of the grapevine nursery propagation process as a source of Phaeoacremonium spp. and Phaeomoniella chlamydospora and occurrence of trunk disease pathogens in rootstock mother vines in Spain. European Journal of Plant Pathology 126: 165-174 
Baranek M., Armengol J., Holleinova V., Pecenka J., Calzarano F., ... Eichmeier A., 2018. Incidence of symptoms and fungal pathogens associated with grapevine trunk diseases in Czech vineyards: first example from a north-eastern European grape-growing region. Phytopathologia Mediterranea 57(3): 449458.

Beck H.E., Zimmermann N.E., McVicar T.R., Vergopolan N., Berg A., Wood E.F., 2018. Present and future Köppen-Geiger climate classification maps at 1-km resolution. Nature Scientific Data 5: 180214.

Berraf A., Péros J.P., 2005. Importance of Eutypa dieback and esca in Algeria and structure of the associated fungal community. (Importance de l'eutypiose et de l'esca en Algérie et structure de la communauté fongique associée.). Journal International des Sciences de la Vigne et du Vin 39(3): 121-128.

Bertsch C., Ramírez-Suero M., Magnin-Robert M., Larignon P., Chong J., ...Fontaine F., 2013. Grapevine trunk diseases: Complex and still poorly understood. Plant Pathology 62(2): 243-265.

Bester M.C., Halleen F., Mostert L. 2015. A PCR detection system for South African basidiomycetous isolates from esca affected grapevine. Australasian Plant Pathology 44: 647-651.

Blanchette R., 1991. Delignification by wood-decay fungi. Annual Review of Phytopathology 29: 381-398.

Bonnet L.O., 1926. A promising remedy for black measles of the vine. In: College of Agriculture. Agricultural Experiment Station, University of California, College of Agriculture, Agricultural Experiment Station, Berkeley, CA, USA, Circular 303, 10 p.

Boraston A.B., Bolam D.N., Gilbert H.J., Davies G.J., 2004. Carbohydrate-binding modules: fine-tuning polysaccharide recognition. Biochemical Journal 382 (Pt 3): 769-781.

Bortolami G., Gambetta G.A., Delzon S., Lamarque L.J., Pouzoulet J., ... Delmas C.E.L., 2019. Exploring the hydraulic failure hypothesis of esca leaf symptom formation. Plant Physiology 181: 1163-1174.

Bortolami G., Farolfi E., Badel E., Burlett R., Cochard H., ... Delmas C.E.L., 2021. Seasonal and long-term consequences of esca grapevine disease on stem xylem integrity. Journal of Experimental Botany 72(10): 3914-3928.

Brown A. A. A., Lawrence D. P. P., Baumgartner K., 2020. Role of basidiomycete fungi in the grapevine trunk disease esca. Plant Pathology 69(2): 205-220.

Bruez E., Lecomte P., Grosman J., Doublet B., Bertsch C., ... Rey P., 2013. Overview of grapevine trunk diseases in France in the 2000s. Phytopathologia Mediterranea 52(2): 262-275.
Bruez E., Vallance J., Gerbore J., Lecomte P., Da Costa J. P., ... Rey P., 2014. Analyses of the temporal dynamics of fungal communities colonizing the healthy wood tissues of esca leaf-symptomatic and asymptomatic vines. PLoS ONE 9(5): e95928.

Bruez E., Larignon P., Bertsch C., Rey P., Fontaine F., 2017. Comparison of the wood-microbiome from Grapevine Trunk Disease-plants, treated or not with sodium arsenite. Phytopathologia Mediterranea 56(3): 560-561 (Abstract).

Bruez E., Vallance J., Gautier A., Laval V., Compant S., ... Rey P., 2020. Major changes in grapevine wood microbiota are associated with the onset of esca, a devastating trunk disease. Environmental Microbiology 22(12): 5189-5206.

Bruez E., Larignon P., Bertsch C., Robert-Siegwald G., Lebrun M.-H., ... Fontaine F., 2021. Impacts of sodium arsenite on wood microbiota of esca-diseased grapevines. Journal of Fungi 7: 498.

Bruno G., Muzzarelli R.A.A., Muzzarelli C., Sparapano L., 2001. Biological activity of chitosan and its derivatives on plant pathogenic or antagonistic fungi and on host plants. In: Proceedings of the 11th Congress of the Mediterranean Phytopathological Union and $3^{\text {rd }}$ Congress of the Sociedade Portuguesa de Fitopatologia, 17-20 September 2001, University of Évora, Évora, Portugal, 104-106.

Bruno G., Sparapano L., 2006a. Effects of three escaassociated fungi on Vitis vinifera L.: III. Enzymes produced by the pathogens and their role in fungus-to-plant or in fungus-to-fungus Interactions. Physiological and Molecular Plant Pathology 69: 182-194.

Bruno G., Sparapano L., 2006b. Effects of three esca-associated fungi on Vitis vinifera L.: II. Characterization of biomolecules in xylem sap and leaves of healthy and diseased vines. Physiological and Molecular Plant Pathology 69: 195-208.

Bruno G., Sparapano L., 2006c. Effects of three esca-associated fungi on Vitis vinifera L.: I. Characterization of secondary metabolites in culture media and host responses to the pathogens in calli. Physiological and Molecular Plant Pathology 69: 209-223.

Bruno G., Sparapano L., 2006d. Effects of three esca-associated fungi on Vitis vinifera L.: V. Changes in the chemical and biological profle of xylem sap from diseased cv. sangiovese vines. Physiological and Molecular Plant Pathology 71: 210-29.

Calzarano F., Cichelli A., Odoardi M., 2001. Preliminary evaluation of variations in composition induced by esca on cv. Trebbiano d'Abruzzo grapes and wines. Phytopathologia Mediterranea 40: 443-448. 
Calzarano F., Di Marco S., 2007. Wood discoloration and decay in grapevines with esca proper and their relationship with foliar symptoms. Phytopathologia Mediterranea 46: 96-101.

Calzarano F., Amalfitano C., Seghetti L., Cozzolino V., 2009. Nutritional status of vines affected with esca proper. Phytopathologia Mediterranea 48: 20-31.

Calzarano F., Osti F., D’agostino V., Pepe A., Di Marco S., 2017. Mixture of calcium, magnesium and seaweed affects leaf phytoalexin contents and grape ripening on vines with grapevine leaf stripe disease. Phytopathologia Mediterranea 56(3): 445-457.

Calzarano F., Osti F., Baránek M., Di Marco S., 2018a. Rainfall and temperature influence expression of foliar symptoms of grapevine leaf stripe disease (esca complex) in vineyards. Phytopathologia Mediterranea 57(3): 488-505.

Calzarano F., Di Marco S., 2018b. Further evidence that calcium, magnesium and seaweed mixtures reduce grapevine leaf stripe symptoms and increase grape yields. Phytopathologia Mediterranea 57: 459-471.

Calzarano F., Pagnani G., Pisante M., Bellocci M., Cillo G., ... Di Marco, S., 2021. Factors involved on tigerstripe foliar symptom expression of esca of grapevine. Plants 10(6): 1041.

Carlucci A., Raimondo M.L., Cibelli F., Phillips A.J.L., Lops F., 2013. Pleurostomophora richardsiae, Neofusicoccum parvum and Phaeoacremonium aleophilum associated with a decline of olives in southern Italy. Phytopathologia Mediterranea 52(3): 517-527.

Canessa P., Larrondo L.F., 2013. Environmental responses and the control of iron homeostasis in fungal systems. Applied Microbiology and Biotechnology 97: 939-955.

Castanera R., Borgognone A., Pisabarro A.G., Ramírez L., 2017. Biology, dynamics, and applications of transposable elements in basidiomycete fungi. Applied Microbiology and Biotechnology 101: 1337-1350.

Castillo J.A., Plata G., 2016. The expansion of brown rot disease throughout Bolivia: possible role of climate change. Canadian Journal of Microbiology 62: 442-448.

Chen H., Cui B.K., 2017. Multi-locus phylogeny and morphology reveal five new species of Fomitiporia (Hymenochaetaceae) from China. Mycological Progress 16(7): 687-701.

Chen J.J., Wu Y.D, Ji X.H., Gates G., Xu X., 2021. A new species of Fomitiporia (Hymenochaetales) from Australia. Phytotaxa 489(2): 200-208.

Chiarappa L., 1997. Phellinus igniarius: the cause of spongy wood decay of black measles ("esca") disease of grapevines. Phytopathologia Mediterranea 36: 109111.
Cholet C., Bruez E., Lecomte P., Rey P., Boury T., ... Geny-Denis L., 2019. Intérêt du curetage dans la lutte contre l'esca. Phytoma 728: 24-27.

Cholet C., Bruez E., Lecomte P., Barsacq A., Martignon T., ... Gény L., (2021). Plant resilience and physiological modifications induced by curettage of Escadiseased grapevines. OENO One 55(1): 153-169.

Choueiri E., Jreijiri F., Chlela P., Mayet V., Comont G., ... Lecomte P., 2014. Fungal community associated with grapevine wood lesions in Lebanon. OENO One 48(4): 293-302.

Ciccarone C., Graniti A., Schiaffino A., Marras F., 2004. Molecular analysis of Fomitiporia mediterranea isolates from esca-affected grapevines in southern Italy. Phytopathologia Mediterranea 43: 268-272.

Claverie M., Notaro M., Fontaine F., Wéry J., 2020. Current knowledge on Grapevine Trunk Diseases with complex etiology: a systemic approach. Phytopathologia Mediterranea 59(1): 29-53.

Cloete M., Fischer M., Mostert L., Halleen F., 2014. A novel Fomitiporia species associated with esca on grapevine in South Africa. Mycological Progress 13: 303-311.

Cloete M., Fischer M., Mostert L., Hallen, F., 2015 a. Hymenochaetales associated with esca-related wood rots on grapevine with a special emphasis on the status of esca in South African vineyards. Phytopathologia Mediterranea 54(2): 299-312.

Cloete M., Mostert L., Fischer M., Halleen F., 2015b. Pathogenicity of South African Hymenochaetales taxa isolated from esca-infected grapevines. Phytopathologia Mediterranea 54(2): 368-379.

Cloete M., Fischer M., Du Plessis I.L., Mostert L., Halleen F., 2016. A new species of Phellinus sensu stricto associated with esca on grapevine in South Africa. Mycological Progress 15(25): 1-9.

Cortesi P., Fischer M., Milgroom M.G., 2000. Identification and spread of Fomitiporia punctata associated with wood decay of grapevine showing symptoms of esca. Phytopathology 90(9): 967-972.

Crous P.W., Gams W., 2000. Phaeomoniella chlamydospora gen. et comb. nov., a causal organism of Petri grapevine decline and esca. Phytopathologia Mediterranea 39: 112-118.

Dai Y.C., Cui B.K., Decock C., 2008 A new species of Fomitiporia (Hymenochaetaceae, Basidiomycota) from China based on morphological and molecular characters. Mycological Research 112(3): 375-80.

Daniel G., 2014. Fungal and Bacterial Biodegradation: White Rots, Brown Rots, Soft Rots, and Bacteria. In: Deterioration and Protection of Sustainable Biomaterials (T.P. Schultz, B. Goodell, D.D. Nicholas, ed.), American Chemical Society, Washington DC, 23-58. 
Decock C., Figueroa S.H., Robledo G., Castillo G., 2007. Fomitiporia punctata (Basidiomycota, Hymenochaetales) and its presumed taxonomic synonyms in America: taxonomy and phylogeny of some species from tropical/subtropical areas. Mycologia 99: 733-752.

Del Frari G., Gobbi A., Aggerbeck M.R., Oliveira H., Hansen L.H., Ferreira R.B., 2019a. Characterization of the wood mycobiome of Vitis vinifera in a vineyard affected by esca. Spatial distribution of fungal communities and their putative relation with leaf symptoms. Frontiers in Plant Science 10: 910.

Del Frari G., Cabral A., Nascimento T., Boavida Ferreira R., Oliveira H., 2019b. Epicoccum layuense a potential biological control agent of esca-associated fungi in grapevine. PLoS ONE 14(3): e0213273.

Del Rivero J.M., García-Marí F., 1984. Ensayo de productos contra la yesca de la vid y la piral de la vid en tratamientos de invierno. Boletin de Sanidad Vegetal, Plagas 10: 17-30.

Deswarte C., Eychenne J., Davy de Virville J., Roustan J., Moreau F., Fallot J., 1996a. Protonophoric activity of eutypine, a toxin from Eutypa lata, in plant mitochondria. Archives of Biochemistry and Biophysics 334: 200-205.

Deswarte C., Canut H., Klaebe A., Roustain J.P., Fallot J., 1996b. Transport, cytoplasmatic accumulation, and mechanism of action of the toxic eutypine in Vitis vinifera cells. Journal of Plant Pathology 149: 336-342.

Di Marco S., Osti F., Mazzullo A., Cesari A., 2001. How iron could be involved in esca fungi development. Phytopathologia mediterranea 40: 449-452.

Di Marco S., Calzarano F., Osti F., Mazzullo A., 2004a. Pathogenicity of fungi associated with a decay of kiwifruit. Australasian Plant Pathology 33: 337-342.

Di Marco S., Osti F., Cesari A., 2004b. Experiments on the control of esca by Trichoderma. Phytopathologia Mediterranea 43(1): 108-115.

Di Marco S., Osti F., 2008. Foliar symptom expression of wood decay in Actinidia deliciosa in relation to environmental factors. Plant Disease 92 (8): 1150-1157.

Di Marco S., Osti F., Mugnai L., 2011. First studies on the potential of a copper formulation for the control of leaf stripe disease within esca complex in grapevine. Phytopathologia Mediterranea 50: S300-S309.

Diaz G.A., Auger J., Besoain X., Bordeu E., Latorre B.A., 2013. Prevalence and pathogenicity of fungi associated with grapevine trunk disease in Chilean vineyards. Ciencia e Investigación Agraria 40(2): 327-339.

Dietzel K., Valle D., Fierer N., U’Ren J.M., Barberan A., 2019. Geographical distribution of fungal plant pathogens in dust across the United States. Frontiers in Ecology and Evolution 7: 304.
Dutton M., Evans C.S., 1996. Oxalate production by fungi: its role in pathogenicity and ecology in the soil environment. Canadian Journal of Microbiology 42: 881-895.

Edwards J., Marchi G., Pascoe I.G., 2001. Young esca in Australia. Phytopathologia Mediterranea 40: 303-310.

Elena K., Paplomatas E.J., 2002. First report of Fomitiporia punctata infecting Kiwi fruit. Plant Disease 86: 1176.

Elena K., Fischer M., Dimou D., Dimou D.M., 2006. Fomitiporia mediterranea infecting citrus trees in Greece. Phytopathologia Mediterranea 45(1): 35-39.

Elena G., Bruez E., Rey P., Luque J., 2018. Microbiota of grapevine woody tissues with or without esca-foliar symptoms in northeast Spain. Phytopathologia Mediterranea 57: 425-438.

Eskalen A., Gubler W.D., 2001. Association of spores of Phaeomoniella chlamydospora, Phaeoacremonium inflatipes, and Pm. aleophilum with grapevine cordons in California. Phytopathologia Mediterranea 40: 429-431.

Eskalen A., Feliciano J., Gubler W.D., 2007. Susceptibility of grapevine pruning wounds and symptom development in response to infection by Phaeoacremonium aleophilum and Phaeomoniella chlamydospora. Plant Disease 91(9): 1100-1104.

Farashiyani A., Mousavi Jorf S., Karimi M., 2012. Study of esca disease of grapevine in bojnourd. Iranian Journal of plant pathology 48: 143-153.

Fiasson J.L., Niemelä T., 1984. The Hymenochaetales: a revision of the European poroid taxa. Karstenia 24(1): 14-28.

Fischer M., 1987. Biosystematische Untersuchungen an den Porlingsgattungen Phellinus Quél. und Inonotus Karst. Bibliotheca Mycologica 107: 1-133.

Fischer M., 1996. On the species complexes within Phellinus: Fomitiporia revisited. Mycological Research 100: 1459-1467.

Fischer M., 2002. A new wood-decaying basidiomycete species associated with esca of grapevine: Fomitiporia mediterranea (Hymenochaetales). Mycological Progress 1(3): 315-324.

Fischer M., Kassemeyer H.H., 2003. Fungi associated with Esca disease of grapevine in Germany. Vitis 42(3): 109-116.

Fischer M., Binder M., 2004. Species recognition, geographic distribution and host-pathogen relationships: A case study in a group of lignicolous basidiomycetes, Phellinus s.l. Mycologia 96(4): 799-811.

Fischer M., Edwards J., Cunnington J.H., Pascoe I.G., 2005. Basidiomycetous pathogens on grapevine: a new species from Australia - Fomitiporia australiensis. Mycotaxon 91: 85-96. 
Fischer M., 2006. Biodiversity and geographic distribution of basidiomycetes causing esca-associated white rot in grapevine: A worldwide perspective. Phytopathologia Mediterranea 45(4): 30-42.

Fischer M., 2009. Nischengebundene Sippenbildung bei Holz bewohnenden Pilzen - experimentelle Befunde. In: Bayer. Akademie der Wissenschaften (Hrsg.): Ökologische Rolle von Pilzen. Rundgespräche der Kommission für Ökologie, 37. Pfeil, München, Germany, 53-62.

Fischer M., 2012. Ein Basidiomycet als Neubürger: Vorkommen und Ausbreitung von Fomitiporia mediterranea (Hymenochaetales) in den badischen Weinbaugebieten, mit Hinweisen zum Vorkommen in Deutschland. Andrias 19: 229-236.

Fischer M., González-García V., 2015. An annotated checklist of European basidiomycetes related to white rot of grapevine (Vitis vinifera). Phytopathologia Mediterranea 54(2): 281-298.

Fischer M., Peighami-Ashnaei S., 2019. Grapevine, esca complex, and environment: The disease triangle. Phytopathologia Mediterranea 58(1): 17-37.

Fischer M., 2019. Grapevine trunk diseases in German viticulture. III. Biodiversity and spatial distribution of fungal pathogens in rootstock mother plants and possible relation to leaf symptoms. Vitis: Journal of Grapevine Research 58(4): 141-149.

Floudas D., Binder M., Riley R., Barry K., Blanchette R.A., ... Hibbett D.S., 2012. The Paleozoic origin of enzymatic lignin decomposition reconstructed from 31 fungal genomes. Science 336: 1715-1719.

Fontaine F., Gramaje D., Armengol J., Smart R., Nagy Z.A., ... Corio-Costet, M.F., 2016a. Grapevine trunk diseases: a review. 1st ed. OIV Publications, Paris, France, 24p.

Fontaine F., Pinto C., Vallet J., Clément C., Gomes A.C., Spagnolo A., 2016b. The effects of grapevine trunk diseases (GTDs) on vine physiology. European Journal of Plant Pathology 144(4): 707-721.

Fussler L., Kobes N., Bertrand F., Maumy M., Grosman J., Savary S., 2008. A characterization of grapevine trunk diseases in France from data generated by the National Grapevine Wood Diseases Survey. Phytopathology 98(5): 571-579.

Garcia Benavides P., Martin Zamorano P., Ocete Perez C.A., Maistrello L., Ocete Rubio R., 2013. Biodiversity of pathogenic wood fungi isolated from Xylotrechus arvicola (Olivier) galleries in vine shoots. Journal International des Sciences de la Vigne et du Vin 47: 73-81.

Gard M., 1922. L’Apoplexie de la Vigne et les formes résupinées du Fomes igniarius (L.) Fries. Bulletin de la
Société de pathologie végétale de France IX (1) (séances de Janvier) 22-28.

Gatica M., Césari C., Escoriaza G., 2004. Phellinus species inducing hoja de malvón symptoms on leaves and wood decay in mature field-grown grapevines. Phytopathologia Mediterranea 43: 59-65.

Gellon M., Fuchs J., Farine S., Mazet F., Laloue H., ... Bertsch C., 2017. A new mode of treatment to cure GTDs: vegetal endotherapy? Phytopathologia Mediterranea 56(3): 572-573 (Abstract).

Girometta C.E., Bernicchia A., Baiguera R.M., Bracco, F., Buratti S., ... Savino E., 2020. An italian research culture collection of wood decay fungi. Diversity 12(2): 58.

Goddard M.L., Boos A., Larignon P., Fontaine F., Bertsch C., Tarnus C., 2017. Arsenite experiments in the program CASDAR V1301 - Arsenic speciation in grapevines and impact on fungal population. Phytopathologia Mediterranea 56(3): 573-574 (Abstract).

Goodell B., Jellison J., Liu J., Daniel G., Paszczynski A., ... Xu G., 1997. Low molecular weight chelators and phenolic compounds isolated from wood decay fungi and their role in the fungal biodegradation of wood. Journal of Biotechnology 53: 133-162.

Goodell B., 2020. Fungi Involved in the Biodeterioration and Bioconversion of Lignocellulose Substrates. In: The Mycota (A Comprehensive Treatise on Fungi as Experimental Systems for Basic and Applied Research) vol 2. Genetics and Biotechnology (Benz J.P., Schipper K., eds.), Springer, Cham, Switzerland, 369-397.

Goufo P., Marques A. C., Cortez I., 2019. Exhibition of local but not systemic induced phenolic defenses in Vitis vinifera L. affected by brown wood streaking, grapevine leaf stripe, and apoplexy (esca complex). Plants 8(10): 412.

Gramaje D., Armengol J., 2011. Fungal trunk pathogens in the grapevine propagation process: potential inoculum sources, detection, identification, and management strategies. Plant Disease 95(9): 1040-1055.

Gramaje D., Mostert L., Groenewald J.Z., Crous P.W., 2015. Phaeoacremonium: From esca disease to phaeohyphomycosis. Fungal Biology 119(9): 759-783.

Gramaje D., Urbez-Torres J.R., Sosnowski M.R., 2018. Managing grapevine trunk diseases with respect to etiology and epidemiology: Current strategies and future prospects. Plant Disease 102(1): 12-39.

Graniti A., Surico G., Mugnai L., 1999. Considerazioni sul mal dell'esca e sulle venature brune del legno della vite. Informatore Fitopatologico 49(5): 6-12.

Grigoriev I.V., Cullen D., Goodwin S.B., Hibbett D., Jeffries, ... Baker S.E., 2011. Fueling the future with fungal genomics. Mycology 2(3): 192-209. 
Grigorie I.V., Nikitin R., Haridas S., Kuo A., Ohm R., ... Shabalov I., 2014. MycoCosm portal: gearing up for 1000 fungal genomes. Nucleic Acids Research 42(D1): D699-D704.

Grosman J., 2008. Observatoire national des maladies du bois: bilan de 4 années d'observations. In: Euroviti Colloque viticole et onologique, Angers, France, 8-17.

Grosman J., Doublet B., 2012. Maladies du bois de la vigne. Synthèse des dispositifs d'observation au vignoble, de l'observatoire 2003-2008 au réseau d’épidémio-surveil- lance actuel. Phytoma 651: 31-35.

Guan X., Essakhi S., Laloue H., Nick P., Bertsch C., Chong J., 2016. Mining new resources for grape resistance against Botryosphaeriaceae: A focus on Vitis vinifera subsp. sylvestris. Plant Pathology 65(2): 273-284.

Guérin-Dubrana L., Labenne A., Labrousse J.C., Bastien S., Rey P., Gegout-Petit A., 2013. Statistical analysis of grapevine mortality associated with esca or eutypa dieback foliar expression. Phytopathologia Mediterranea 52: 276-288.

Guérin-Dubrana L., Fontaine F., Mugnai L., 2019. Grapevine trunk disease in European and Mediterranean vineyards: occurrence, distribution and associated disease-affecting cultural factors. Phytopathologia Mediterranea 58(1): 49-71.

Haidar R., Roudet J., Bonnard O., Dufour M.C., CorioCostet M.F., ... Fermaud M., 2016. Screening and modes of action of antagonistic bacteria to control the fungal pathogen Phaeomoniella chlamydospora involved in grapevine trunk diseases. Microbiological Research 192: 172-184.

Haidar R., Yacoub A., Vallance J., Compant S., Antonielli L., ... Rey P., 2021. Bacteria associated with wood tissues of Esca-diseased grapevines: functional diversity and synergy with Fomitiporia mediterranea to degrade wood components. Environmental Microbiology. doi: 10.1111/1462-2920.15676

Halbwachs H., Simmel J., Bassler C., 2016. Tales and mysteries of fungal fruiting: How morphological and physiological traits affect a pileate lifestyle. Fungal Biology Review 30(2): 36-61.

Halleen F., Crous P.W., Petrini O., 2003. Fungi associated with healthy grapevine cuttings in nurseries, with special reference to pathogens involved in the decline of young vines. Australasian Plant Pathology 32: 47-52.

Hofman M.T., Arnold A.E., 2008. Geographic locality and host identity shape fungal endophyte communities in cupressaceous trees. Mycological Research 112: 331-344.

Hofstetter V., Buyck B., Croll D., Viret O., Couloux A., Gindro K., 2012. What if esca disease of grapevine were not a fungal disease? Fungal Diversity 54: 51-67.
Hyde K.D., Xu J., Rapior S., Jeewon R., Lumyong S., ... Stadler M., 2019. The amazing potential of fungi: 50 ways we can exploit fungi industrially. Fungal Diversity 97: 1-136.

Jamaux-Despréaux I., Péros J.P., 2003. Genetic structure in populations of the fungus Fomitiporia punctata associated with esca syndrome in grapevine. Vitis 42(1): 43-51.

James T.Y., Srivilai P., Kües U., Vilgalys R., 2006. Evolution of the bipolar mating system of the mushroom Coprinellus disseminatus from its tetrapolar ancestors involves loss of mating type-specific pheromone receptor function. Genetics 172: 1877-1891.

James T.Y., Sun S., Li W.J., Heitman J., Kuo H.C., ... Olson A., 2013. Polyporales genomes reveal the genetic architecture underlying tetrapolar and bipolar mating systems. Mycologia 105: 1374-1390.

John S., Wicks, T.J., Hunt J.S., Lorimer M.F., Oakey H., Scott E.S., 2005. Protection of grapevine pruning wounds from infection by Eutypa lata. Australasian Plant Pathology 34: 569-575.

Karimi M.R., Mahmoodi B., Kazemiyan M., 2001. First report of esca of grapevine in Iran. Phytopathologia Mediterranea 40: S481 (Abstract).

Kuan I.-C., Tien M., 1993. Stimulation of Mn peroxidase activity: a possible role for oxalate in lignin biodegradation. PNAS - Proceedings of the National Academy of Sciences of the United States of America 90(4): 1242-1246.

Kües U., 2013. Mating type genes as master regulators of mushroom development. In: Proceedings of the 7 th International Medicinal Mushroom Conference (Chinese Academy of Engineering, China Chamber of Commerce of Foodstuffs and Native Products, ed.), Jiangsu Alphay Biological Technology Co., Nantong City, China, 33-59.

Kües U., 2015. From two to many: Multiple mating types in Basidiomycetes. Fungal Biology Reviews 29 (3-4): 126-166.

Kuntzmann P., Villaume S., Larignon P., Bertsch C., 2010. Esca, BDA and Eutypiosis: Foliar symptoms, trunk lesions and fungi observed in diseased vinestocks in two vineyards in Alsace. Vitis - Journal of Grapevine Research 49(2): 71-76.

Kraus C., Vögele R., Fischer M., 2019. The Esca complex in German vineyards: does the training system influence occurrence of GLSD symptoms? European Journal of Plant Pathology 155: 265-279.

Lafon R., 1921. Modifications à apporter à la taille de la vigne des Charentes, taille Guyot-Poussart mixte et double: l'apoplexie, traitement préventif (méthode Poussard), traitement curatif. Imp. Roumégous et Déhan, Montpellier, France, 96 pp. 
Larignon P., Dubos B., 1997. Fungi associated with Esca disease in grapevine. European Journal of Plant Pathology 103: 147-157.

Larignon P., Dubos B., 2000. Preliminary studies on the biology of Phaeoacremonium. Phytopathologia Mediterranea 39: 184-189.

Larignon P., Giansetto K., Salancon E., Girardon K., Berud F., ... Coarer M., 2008a. Champignons associés aux maladies du bois: une enquête en pépinières. Rhône en VO - Revue de Viticulture et d'Oenologie de la Vallée du Rhône 3: 26-31.

Larignon P., Darne G., Menard E., Desache F., Dubos B., 2008b. Comment agissait l'arsénite de sodium sur l'esca de la vigne? Progrès Agricole et Viticole 125: 642-651.

Laveau C., Letouze A., Louvet G., Bastien S., GuérinDubrana L., 2009. Differential aggressiveness of fungi implicated in esca and associated diseases of grapevine in France. Phytopathologia Mediterranea, 48(1): 32-46.

Lecomte P., Darrieutort G., Liminana J.-M., Comont G., Muruamendiaraz A, ... Fermaud, M. 2012. New insights into esca of grapevine: the development of foliar symptoms and their association with xylem discoloration. Plant Disease 96: 924-934.

Lecomte P., Diarra B., Carbonneau A., Rey P., Chevrier C., 2018. Esca of grapevine and training practices in France: results of a 10-year survey. Phytopathologia Mediterranea 57: 472-487.

Letousey P., Bailleul F., Perrot G., Rabenoelina F., Boulay M., ... Fontaine F., 2010. Early events prior to visual symptoms in the apoplectic form of grapevine esca disease. Phytopathology 100: 424-431.

Levasseur A., Drula E., Lombard V., Coutinho P.M., Henrissat B., 2013. Expansion of the enzymatic repertoire of the CAZy database to integrate auxiliary redox enzymes. Biotechnology for Biofuels 6(1): 41.

Li S., Bonneu F., Chadoeuf J., Picart D., Gégout-Petit A., Guérin-Dubrana L., 2017. Spatial and temporal pattern analyses of esca grapevine disease in vineyards in France. Phytopathology 107(1): 59-69.

Liaud N., Giniés C., Navarro D., Fabre N., Crapart S., Sigoilloit J.C., 2014. Exploring fungal biodiversity: organic acid production by 66 strains of filamentous fungi. Fungal Biology and Biotechnology 1(1): 1.

Lombard V., Golaconda Ramulu H., Drula E., Coutinho P.M., Henrissat B., 2014. The Carbohydrate-active enzymes database (CAZy) in 2013. Nucleic Acids Research 42: D490-D495.

Lorrain B., Ky I., Pasquier G., Jourdes M., Dubrana L.G., Gény L., ... Teissedre P.L., 2012. Effect of Esca disease on the phenolic and sensory attributes of Cab- ernet Sauvignon grapes, musts and wines. Australian Journal of Grape and Wine Research 18: 64-72.

Lundell T.K., Mäkelä M.R., de Vries R.P., Hildén K.S., 2014. Chapter Eleven - Genomics, lifestyles and future prospects of wood-decay and litter-decomposing Basidiomycota. In: Advances in Botanical Research, (Francis M. Martin, ed.), Academic Press, 70, 329-370.

Luque J., Martos S., Aroca A., Raposo R., Garcia-Figueres F., 2009. Symptoms and fungi associated with declining mature grapevine plants in northeast Spain. Journal of Plant Pathology 91(2): 381-390.

Magarey P. A., Carter M.V., 1986. New technology facilitates control of Eutypa dieback in apricots and grapevines. Plant Protection Quarterly 1: 156-159

Maher N., Piot J., Bastien S., Vallance J., Rey P., GuérinDubrana, L., 2012. Wood necrosis in ESCA-affected vines: Types, relationships and possible links with foliar symptom expression. Journal International Des Sciences de La Vigne et Du Vin 46(1): 15-27.

Marchi G., 2001. Susceptibility to esca of various grapevine (Vitis vinifera) cultivars grafted on different rootstocks in a vineyard in the province of Siena (Italy). Phytopathologia Mediterranea 40(1): 27-36.

Marchi G., Peduto F., Mugnai L., Di Marco S., Calzarano F., Surico G., 2006. Some observations on the relationship of manifest and hidden esca to rainfall. Phytopathologia Mediterranea 45: 117-126.

Markakis A.M., Kavroulakis N., Ntougias S., Koubouris G.C., Sergentani C.K., Ligoxigakis E.K., 2017. Characterization of fungi associated with wood decay of tree species and grapevine in Greece. Plant Disease (101): 1929-1940.

Markakis E.A., Ligoxigakis E.K., Roussos, P.A., Sergentani C.K., Kavroulakis N., ... Koubouris, G.C., 2019. Differential susceptibility responses of Greek olive cultivars to Fomitiporia mediterranea. European Journal of Plant Pathology 153: 1055-1066.

Martin M.T., Cobos R., 2007. Identification of fungi associated with grapevine decline in Castilla y Leon (Spain). Phytopathologia Mediterranea 46: 18-25.

Masi M., Cimmino A., Reveglia P., Mugnai L., Surico G., Evidente A., 2018. Advances on fungal phytotoxins and their role in grapevine trunk diseases. Journal of Agricultural and Food Chemistry 66(24): 5948-5958.

Mazzullo A., Di Marco S., Osti F., Cesari A., 2000. Bioassays on the activity of resveratrol, pterostilbene and phosphorous acid towards fungi associated with esca of grapevine. Phytopathologia Mediterranea 39(3): 357-365.

Mirabolfathy M., Hosseinian L., Peighami Ashnaei S., 2021. Fungal communities of grapevine decline 
in the main grapegrowing regions of Iran. Indian Phytopathology: 1-7.

Mirsoleymani Z., Mostowfizadeh Ghalamfarsa R., 2019. Fomitiporia mediterranea, a new basidiomycete species for mycobiota of Iran. Rostaniha 19: 189-191.

Mohammadi H., Banihashemi Z., Gramaje D., Armengol J., 2013. Fungal pathogens associated with grapevine trunk diseases in Iran. Journal of Agriculture, Science and Technology 15:137-150.

Mondello V., Larignon P., Armengol J., Kortekamp A., Vaczy K., ... Fontaine F., 2018a. Management of grapevine trunk diseases: knowledge transfer, current strategies and innovative strategies adopted in Europe. Phytopathologia Mediterranea 57 (3): 369-383.

Mondello V., Songy A., Battiston E., Pinto C., Coppin C., ... Fontaine F., 2018b. Grapevine trunk diseases: A review of fifteen years of trials for their control with chemicals and biocontrol agents. Plant Disease 102(7): 1189-1217.

Montanari E., 2010. Per una storia linguistica di Esca. In: Il mal dellesca della vite (G. Surico, L. Mugnai, ed.), ARSIA Regione Toscana, Firenze, Italy, 26-34.

Morel M., Meux E., Mathieu Y., Thuillier A., Chibani K., ... Gelhaye, E., 2013. Xenomic networks variability and adaptation traits in wood decaying fungi: Fungal xenomic networks. Microbial Biotechnology 6: 248-263.

Moret F., Lemaître-Guillier C., Grosjean C., Clément G., Coelho C., ... Adrian M., 2019. Clone-dependent expression of esca disease revealed by leaf metabolite analysis. Frontiers in Plant Science 9: 1960.

Moret F., Delorme G., Clément G., Grosjean C., Lemaître-Guillier C., ... Fontaine F., 2021. Esca-affected grapevine leaf metabolome is clone- and vintagedependent. Physiologia Plantarum 171: 424-434.

Moretti S., Pierron R., Pacetti A., Gellon M., Tarnus C., ... Farine S. 2019. Non-Enzymatic in lignum degradation mechanism: a way to control Grapevine Trunk Disease? Phytopathologia Mediterranea 58(2): 414415 (Abstract).

Morgenstern I., Robertson D.L., Hibbett D.S., 2010. Characterization of three mnp genes of Fomitiporia mediterranea and report of additional class ii peroxidases in the order Hymenochaetales. Applied and Environmental Microbiology 76(19): 6431-6440.

Mostert L., Halleen F., Fourie P., Crous P.W., 2006. A review of Phaeoacremonium species involved in Petri disease and esca of grapevines. Phytopathologia Mediterranea 45: S12-S29.

Mugnai L., Bertelli E., Surico G., Bruno E., 1997. Effetto di alcune sostanze fenoliche sulla crescita di funghi del legno di viti colpite dal "mal dellesca". Petria 7: $35-46$.
Mugnai L., Graniti A., Surico G., 1999. Esca (black measles) and brown wood-streaking: two old and elusive diseases of grapevines. Plant Disease 83(5): 404-418.

Mugnai L., Guiggiani M., Bazzo F., Marchi G., Surico G., 2010. Il mal dell'esca e la carie bianca del legno: agenti causali, sintomatologia e casi studio di esca giovane. In: Il mal dellesca della vite (G. Surico, L. Mugnai, ed.), ARSIA Regione Toscana, Firenze, Italy, 65-88.

Murolo S., Romanazzi G., 2014. Effects of grapevine cultivar, rootstock and clone on esca disease. Australasian Plant Pathology 43: 215-221.

Nascimento T., Rego C., Oliveira H., 2007. Potential use of chitosan in the control of grapevine trunk diseases. Phytopathologia Mediterranea 46: 218-224.

Niem J.M., Billones-Baaijens R., Stodart B., Savocchia S., 2020. Diversity profiling of grapevine microbial endosphere and antagonistic potential of endophytic Pseudomonas against grapevine trunk diseases. Frontiers in Microbiology 11: 477.

Olmo D., Gramaje D., Armengol J., 2017. Hongos asociados a las enfermedades de la madera del almendro en la Isla de Mallorca. Revista de Fruticultura 54: 18-29.

Osti F., Di Marco S., 2010. Iron-dependent, non-enzymatic processes promoted by Phaeomoniella chlamydospora and Phaeoacremonium aleophilum, agents of esca in grapevine. Physiological and Molecular Plant Pathology 74(5-6): 309-316.

Ouadi L., Bruez E., Bastien S., Vallance J., Lecomte P., ... Rey P., 2019. Ecophysiological impacts of Esca, a devastating grapevine trunk disease, on Vitis vinifera $\mathrm{L}$. PLoS ONE 14(9): e0222586.

Pacetti A., Pierron R., Farine S., Mugnai L., Tarnus C., ... Gellon M., 2019. Vertical vegetal endotherapy: a new mode of treatment to cure grapevine trunk diseases? Phytopathologia Mediterranea 58(2): 426 (Abstract).

Pacetti A., Moretti S., Pinto C., Compant S., Farine S., ... Mugnai L., 2021. Trunk surgery as a tool to reduce foliar symptoms in diseases of the esca complex and its influence on vine wood microbiota. Journal of Fungi 7: 521.

Paplomatas E.J., Elena K., Tsopelas P., Tzima A., Paraskevopoulus A., Papanikolaou A., 2006. Infection of olive trees with the fungus Fomitiporia punctata (Phellinus punctatus). Phytopathologia Mediterranea 45(1): 69 (Abstract).

Pérez J., Muñoz-Dorado J., de la Rubia T., Martínez J., 2002. Biodegradation and biological treatments of cellulose, hemicellulose and lignin: an overview. International Microbiology 5: 53-63.

Péros J.-P., Berger G., Jamaux-Despréaux I., 2008. Symptoms, wood lesions and fungi associated with Esca in organic vineyards in Languedoc-Roussillon (France). Journal of Phytopathology 156: 297-303. 
Pilotti M., Gervasi F., Brunetti A., 2005. Molecular identification of Fomitiporia mediterranea and Eutypa latal Libertella blepharis in Platanus acerifolia. Journal of Phytopathology 153: 193-202.

Pilotti M., Tizzani L., Brunetti A., Gervasi F., Di Lernia G., Lumia V., 2010. Molecular identification of Fomitiporia mediterranea on declining and decayed hazelnut. Journal of Plant Pathology 92(1): 115-129.

Polemis E., Dimou D.M., Fryssouli V., Zervakis G.I., 2019. Diversity of saproxylic basidiomycetes in Quercus ilex woodlands of central and insular Greece. Plant Biosystem 153: 385-397

Pollastro S., Dongiovanni C., Abbatecola A., Faretra F., 2000. Observations on the fungi associated with esca and on spatial distribution of esca-symptomatic plants in Apulian (Italy) vineyards. Phytopathologia Mediterranea 39(1): 206-210.

Pollastro S., Dongiovanni C., Abbatecola A., De Guido, M.A., De Miccolis Angelini R. M., Faretra F., 2001. Specific SCAR primer for fungi associated with wood decay of grapevine. Phytopathologia Mediterranea 40: S362-S368.

Pouzoulet J., Pivovaroff A.L., Santiago L.S., Rolshausen P.E., 2014. Can vessel dimension explain tolerance toward fungal vascular wilt diseases in woody plants? Lessons from Dutch elm disease and esca disease in grapevine. Frontiers in Plant Science 5: 253.

Pouzoulet J., Scudiero E., Schiavon M., Rolshausen P.E., 2017. Xylem vessel diameter affects the compartmentalization of the vascular pathogen Phaeomoniella chlamydospora in grapevine. Frontiers in Plant Science 8: 1442.

Pouzoulet J., Scudiero E., Schiavon M., Santiago L.S., Rolshausen P.E., 2019. Modeling of xylem vessel occlusion in grapevine. Tree Physiology 39: 1438-1445.

Quaglia M., Covarelli L., Zazzerini A., 2009. Epidemiological survey on esca disease in Umbria, central Italy. Phytopathologia Mediterranea 48: 84-91.

Rábai A., Dula T., Mugnai L., 2008. Distribution of esca disease in Hungary and the pathogens causing the syndrome. Acta Phytopathologica et Entomologica Hungarica 43(1): 45-54.

Rajaiyan M., Karimi Shahri M.R., Pirnia M., Dehvari V., Ghezel Sefloo N., 2013. Detection and identification of some fungal agents causing grapevine decline in Northern Khorasan province vineyards using PCR technique. Applied Entomology and Phytopathology 81: 167-177.

Ramsdell D. C., 1995. Winter air-blast sprayer application of benomyl for reduction of Eutypa dieback disease incidence in a concord grape vineyard in Michigan. Plant Disease 79: 399-402.
Ravaz L., 1909. Sur l'apoplexie de la vigne. Progrès Agricole et Viticole 30: 547-579.

Ravaz L., 1919. Encore l'apoplexie de la vigne. Progrès Agricole et Viticole 52: 601-603.

Reisenzein H., Berger N., Nieder G., 2000. Esca in Austria. Phytopathologia Mediterranea 39: 26-34.

Riley R., Salamov A.A., Brown D.W., Nagy L.G., Floudas D., ... Grigoriev I.V., 2014. Extensive sampling of basidiomycete genomes demonstrates inadequacy of the white-rot/brown-rot paradigm for wood decay fungi. PNAS - Proceedings of the National Academy of Sciences of the United States of America 111 (27): 9923-9928.

Roccotelli A., Schena L., Sanzani S.M., Cacciola S.O., Mosca S., ... di San Lio G.M., 2014. Characterization of Basidiomycetes associated with wood rot of citrus in southern Italy. Phytopathology 104: 851-858.

Rolshausen P.E., Greve L.C., Labavitch J.M., Mahoney N.E., Molyneux R.J., Gubler W.D., 2008. Pathogenesis of Eutypa lata in grapevine: identification of virulence factors and biochemical characterization of cordon dieback. Phytopathology 98: 222-229.

Romanazzi G., Murolo S., Pizzichini L., Nardi S., 2009. Esca in young and mature vineyards, and molecular diagnosis of the associated fungi. European Journal of Plant Pathology 125(2): 277-290.

Rubio J.J., Garzón E., 2011. Las enfermedades de madera de vid como amenaza del sector vitícola. Revista Winetech 2 (Noviembre): 18-21.

Rui D., Battel C., 1963. Mise au point d'un nouveau moyen de lutte contre l'esca de la vigne. Notiziario sulle malattie delle piante 63: 9-18.

Rumbos A., Rumbou I., 2001. Fungi associated with esca and young grapevine decline in Greece. Phytopathologia Mediterranea 40 (3): 330-335.

Rusjan D., Persic M., Likar M., Biniari K., Mikulic-Petkovsek M., 2017. Phenolic responses to esca-associated fungi in differently decayed grapevine woods from different trunk parts of "Cabernet Sauvignon." Journal of Agricultural and Food Chemistry 65(31): 6615-6624.

Sánchez-Torres P., Hinarejos R., González V., Tuset J.J., 2008. Identification and characterization of fungi associated with esca in vineyards of the Comunidad Valenciana (Spain). Spanish Journal of Agricultural Research 6(4): 650-660.

Schilling M., Farine S., Péros J.P., Bertsch C., Gelhay E., 2021. Wood degradation in grapevine diseases. In: Advances in Botanical Research, (Mélanie MorelRouhier, Rodnay Sormani, eds.), Academic Press, 99, 175-207.

Schmidt O., Gaiser O., Dujesiefken D., 2012. Molecular identification of decay fungi in the wood of urban 
trees. European Journal of Forest Research 131: 885891.

Shimada M., Ma D.-B., Akamatsu Y., Hattori T., 1994. A proposed role of oxalic acid in wood decay systems of wood-rotting basidiomycetes. FEMS Microbiology Reviews 13(2-3): 285-295.

Siebert J.B., 2001. Eutypa: The economic toll on vineyards. Wines \& Vines (April): 50-56.

Singh Arora D., Kumar Sharma, R., 2010. Ligninolytic fungal laccases and their biotechnological applications. Applied Biochemistry and Biotechnology 160: 1760-1788.

Sista Kameshwar A.K., Qin W., 2020. Systematic metadata analysis of brown rot fungi gene expression data reveals the genes involved in Fenton's reaction and wood decay process. Mycology 11: 22-37.

Sofia J., Goncalves M.T., Oliveira H., 2006. Spatial distribution of esca symptomatic plants in Dão vineyards (centre Portugal) and isolation of associated fungi. Phytopathologia Mediterranea 45: 87-92.

Songy A., Fernandez O., Clément C., Larignon P., Fontaine F., 2019a. Grapevine trunk diseases under thermal and water stresses. Planta 249(6): 1655-1679.

Songy A., Vallet J., Gantet M., Boo A., Ronot P., ... Fontaine F., 2019b. Sodium arsenite effect on Vitis vinifera L. Physiology. Journal of Plant Physiology 238: 72-79.

Sparapano L., Bruno G., Graniti A., 1998. Esopolisaccaridi fitotossici sono prodotti in coltura da due specie di Phaeoacremonium associate al complesso del 'mal dell'esca' della vite. Petria 8: 210-212.

Sparapano L., Bruno G., Ciccarone C., Graniti A., 2000a. Infection of grapevines by some fungi associated with esca. I. Fomitiporia punctata as a wood-rot inducer. Phytopathologia Mediterranea 39(1): 46-52.

Sparapano L., Bruno G., Ciccarone C., Graniti A., 2000 b. Infection of grapevines by some fungi associated with esca. II. Interaction among Phaeoacremonium chlamydosporum, P. aleophilum and Fomitiporia punctata. Phytopathologia Mediterranea 39: 53-58.

Sparapano L., Bruno G., Graniti A., 2000c. Effects on plants of metabolites produced in culture by Phaeoacremonium chlamydosporum, $P$. aleophilum and Fomitiporia punctata. Phytopathologia Mediterranea 39: 169-177.

Sparapano L., Bruno G., Graniti A., 2001a. Three year observation of grapevines cross-inoculated with escaassociated fungi. Phytopathologia Mediterranea 40: S376-S386.

Sparapano L., Bruno G., Campanella A., 2001b. Interactions between three fungi associated with esca of grapevine, and their secondary metabolites. Phytopathologia Mediterranea 40(3): 417-422.
Spiteller P., 2008. Chemical defence strategies of higher fungi. Chemistry 14(30): 9100-9110.

Spiteller P., 2015. Chemical ecology of fungi. Natural Product Reports 32: 971-993.

Surico G., Marchi G., Ferrandino F.J., Braccini P., Mugnai L., 2000. Analysis of the spatial spread of esca in some tuscan vineyards (Italy). Phytopathologia Mediterranea 39: 211-224.

Surico G., Mugnai L., Marchi G., 2006. Older and more recent observations on esca: A critical overview. Phytopathologia Mediterranea 45(S1): 68-86.

Surico G., 2009. Towards a redefinition of the diseases within the esca complex of grapevine. Phytopathologia Mediterranea 48: 5-10.

Svampa G., Tosatti E.M., 1977. Prove di lotta contro il "mal dell'esca" della vite. Informatore Fitipatologico 12: $21-24$

Svedruzić D., Jónsson S., Toyota C.G., Reinhardt L.A., Ricagno S., ... Richards N.G., 2005. The enzymes of oxalate metabolism: unexpected structures and mechanisms. Archives of Biochemistry and Biophysics 433(1): 176-92.

Tabacchi R., Fkyerat A., Poliar, C., Dubin G. M., 2000. Phytotoxins from fungi of esca of grapevine. Phytopathologia Mediterranea 39(1): 156-161.

Tanaka N., Akamatsu Y., Hattori T., Shimada M. 1994. Effect of oxalic acid on the oxidative breakdown of cellulose by the Fenton reaction. Wood Research: Bulletin of the Wood Research Institute Kyoto University 81: 8-10.

Tauber J.P., Matthäus C., Lenz C., Hoffmeister D., Popp J., 2018. Analysis of basidiomycete pigments in situ by Raman spectroscopy. Journal of Biophotonics 11(6): e201700369.

Thibault M., 2015. Le curetage. In: Les maladies du Bois de la Vigne - Réunion du groupe national Maladies $d u$ Bois de la Vigne, 17-18/11/2015, Université de Haute-Alsace, Colmar, France, 55-57.

Úrbez-Torres J.R., Haag P., Bowen P., O'Gorman D.T., 2014. Grapevine trunk diseases in British Columbia: incidence and characterization of the fungal pathogens associated with esca and petri diseases of grapevine. Plant Disease 98: 469-482.

Urzúa U., Kersten P.J., Vicuña R., 1998. Manganese peroxidase-dependent oxidation of glyoxylic and oxalic acids synthesized by Ceriporiopsis subvermispora produces extracellular hydrogen peroxide. Applied and Environmental Microbiology Journal 64(1): 68-73.

Valtaud C., Larignon P., Roblin G., Fleurat-Lessard P., 2009. Developmental and ultrastructural features of Phaeomoniella chlamydospora and Phaeoacremonium aleophilum in relation to xylem degradation in esca 
disease of the grapevine. Journal of Plant Pathology 91: $37-51$.

Vasquez S.J., Gubler W.D., Leavitt G.M., 2007. Economic loss in California's table grape vineyards due to measles. Phytopathologia Mediterranea 46: 118 (Abstract).

Větrovský T., Kohout P., Kopecký M., Machac A., Man M., ... Baldrian P., 2019. A meta-analysis of global fungal distribution reveals climate-driven patterns. Nature Communication 10: 5142.

Viala P., 1926. Recherches sur les maladies de la vigne. Esca. Annales des Epiphyties 12: 5-108.

Vicent A., García-Figueres F., García-Jiménez J., Armengol J., Torné L., 2001. Fungi associated with esca and grapevine declines in Spain: a three-year survey. Phytopathologia Mediterranea 40: 325-329.

Vinet E., 1909. L'apoplexie de la vigne en Anjou. Revue de Viticulture 32: 676-681.

Wagner T., Fischer M., 2001. Natural groups and a revised system for the European poroid Hymenochaetales (Basidiomycota) supported by nLSU rDNA sequence data. Mycological Research 105: 773-782.

Wagner T., Fischer M., 2002. Proceedings towards a natural classification of the worldwide taxa Phellinus s.l. and Inonotus s.l., and phylogenetic relationships of allied genera. Mycologia 94 (6): 998-1016.

White T.J., Bruns T.D., Lee S., Taylor J.W., 1990. Amplification and direct sequencing of fungal ribosomal RNA genes for phylogenetics. In: PCR protocols (Innis M.A., Gelfand D.H., Sninsky J.J., White T.J., ed.), Academic Press, San Diego, USA, 315-322.

White C.L., Halleen F., Fischer M., Mostert L., 2011. Characterisation of the fungi associated with esca diseased grapevines in South Africa. Phytopathologia Mediterranea 50: 204-223.

Wicks T., Davies K., 1999. The effect of Eutypa on grapevine yield. The Australian and New Zealand Grapegrower \& Winemaker 426a:15-16.

Ye Q., Jia J., Manawasinghe I.S., Li X., Zhang W., ... Yan J., 2021. Fomitiporia punicata and Phaeoacremonium minimum associated with Esca complex of grapevine in China. Phytopathology Research 3: 11.

Zanzotto A., Autiero F., Bellotto D., Dal Cortivo G., Lucchetta G., Borgo M., 2007. Occurrence of Phaeoacremonium spp. and Phaeomoniella chlamydospora in grape propagation materials and young grapevines. European Journal of Plant Pathology 119: 183-192

Zhuang L., Guo W., Yoshida M., Feng X., Goodell B., 2015. Investigating oxalate biosynthesis in the wood-decaying fungus Gloeophyllum trabeum using 13C metabolic flux analysis. RSC Advances 5(126): 104043-104047. 